\title{
Orphan nuclear receptors in breast cancer pathogenesis and therapeutic response
}

\author{
Rebecca B Riggins ${ }^{1}$, Mary M Mazzotta ${ }^{1}$, Omar Z Maniya ${ }^{1}$ \\ and Robert Clarke ${ }^{1,2}$
}

${ }^{1}$ Lombardi Comprehensive Cancer Center and Department of Oncology and ${ }^{2}$ Department of Physiology and Biophysics, Georgetown University School of Medicine, 3970 Reservoir Road NW, Washington, District of Columbia 20057, USA

(Correspondence should be addressed to R Clarke; Email: clarker@georgetown.edu)

\begin{abstract}
Nuclear receptors comprise a large family of highly conserved transcription factors that regulate many key processes in normal and neoplastic tissues. Most nuclear receptors share a common, highly conserved domain structure that includes a carboxy-terminal ligand-binding domain. However, a subgroup of this gene family is known as the orphan nuclear receptors because to date there are no known natural ligands that regulate their activity. Many of the 25 nuclear receptors classified as orphan play critical roles in embryonic development, metabolism, and the regulation of circadian rhythm. Here, we review the emerging role(s) of orphan nuclear receptors in breast cancer, with a particular focus on two of the estrogen-related receptors (ERR $\alpha$ and $E R R \gamma$ ) and several others implicated in clinical outcome and response or resistance to cytotoxic or endocrine therapies, including the chicken ovalbumin upstream promoter transcription factors, nerve growth factor-induced B, DAX-1, liver receptor homolog-1, and retinoic acid-related orphan receptor $\alpha$. We also propose that a clearer understanding of the function of orphan nuclear receptors in mammary gland development and normal mammary tissues could significantly improve our ability to diagnose, treat, and prevent breast cancer.
\end{abstract}

Endocrine-Related Cancer (2010) 17 R213-R231

\section{What is an orphan nuclear receptor?}

Members of the nuclear receptor superfamily are some of the most abundant regulators of gene expression in higher eukaryotes. These DNA-binding transcription factors play essential roles in key biological processes from embryonic development to differentiation, and their dysregulation has been widely studied in many different pathologies including cancer (Mangelsdorf et al. 1995, Robinson-Rechavi et al. 2003, Novac \& Heinzel 2004, Jeong \& Mangelsdorf 2009).

Of the 48 members of the human nuclear receptor superfamily, 25 are currently considered to be orphan nuclear receptors (Benoit et al. 2006; Table 1) because they have no known ligand. Most of these 25 receptors adhere to the classical domain structure that typifies ligand-regulated nuclear receptors (discussed in more detail below), with two notable exceptions. Dosagesensitive sex reversal, adrenal hypoplasia critical region, on chromosome $\mathrm{X}$, gene 1 (DAX-1, NR0B1) and small heterodimerization partner (SHP, NR0B2) lack a classical DNA-binding domain (DBD), and cannot act alone to bind DNA (Burris et al. 1996, Seol et al. 1996). The number of nuclear receptors classified as orphans has decreased over the years as new ligands have been discovered. Two such 'adopted orphans' are the retinoid $\mathrm{X}$ receptors (RXRs) and the peroxisome proliferator-activated receptors (PPARs), which were initially considered to be orphans but have been firmly in the category of liganded receptors for some time. RXRs and PPARs, along with several other formerly orphaned nuclear receptors, form a group now referred to as natural or nutrient sensors that bind 9-cis retinoic acid, oleic, and linoleic acids (Francis et al. 2003, Benoit et al. 2004).

What constitutes an orphan receptor is still the subject of some debate. An example of the lingering 
Table 1 Orphan nuclear receptors in breast cancer

\begin{tabular}{|c|c|c|c|}
\hline Gene symbols & Common name & Select ligand (s) & mRNA overexpression in human breast cancer ${ }^{a}$ \\
\hline NROB1 & DAX-1 & & GSE2109, GSE3744, GSE1477, GSE1561 \\
\hline NROB2 & SHP & & GSE9014 \\
\hline NR1D1 & Rev-Erb $\alpha$ & Heme & $\begin{array}{l}\text { GSE1378, GSE9014, GSE8977, GSE5949, GSE5460, } \\
\text { GSE2109 }\end{array}$ \\
\hline NR1D2 & Rev-Erb $\beta$ & Heme & $\begin{array}{l}\text { GSE2109, GSE3971, GSE10087, GSE1379, GSE5460, } \\
\text { GSE3281, GSE3893 }\end{array}$ \\
\hline NR1F1 & $\mathrm{ROR} \alpha$ & $\begin{array}{l}\text { Cholesterol } \\
\text { derivatives }\end{array}$ & $\begin{array}{l}\text { GSE9014, GSE5460, GSE6861, GSE3744, GSE3893, } \\
\text { GSE5764, GSE1477 }\end{array}$ \\
\hline NR1F2 & $\mathrm{ROR} \beta$ & & GSE3744, GSE9014, GSE5364 \\
\hline NR1F3 & $\mathrm{ROR} \gamma$ & & $\begin{array}{l}\text { GSE2109, GSE1477, GSE10843, GSE5460, GSE9014, } \\
\text { GSE5764 }\end{array}$ \\
\hline$N R 2 A 1$ & HNF4- $\alpha$ & Fatty acids & $\begin{array}{l}\text { GSE9014, GSE10843, GSE5720, GSE5764, GSE8977, } \\
\text { GSE6861, GSE2109, GSE3744, GSE7390 }\end{array}$ \\
\hline$N R 2 A 2$ & HNF4- $\gamma$ & Fatty acids & GSE1561, GSE3744, GSE9014 \\
\hline$N R 2 C 1$ & TR2 & & GSE3744, GSE8977, GSE5847, GSE7390 \\
\hline NR2C2 & TR4 & & GSE3744, GSE5460, GSE2109, GSE1477, GSE9014 \\
\hline NR2E1 & TLX & & GSE7390, GSE3744, GSE2109 \\
\hline NR2E3 & PNR & & GSE5364, GSE2109, GSE10843, GSE1561, GSE5460 \\
\hline$N R 2 F 1$ & COUP-TFI & & GSE5460, GSE2109, GSE1561, GSE3971, GSE9014 \\
\hline NR2F2 & COUP-TFII & & $\begin{array}{l}\text { GSE5364, GSE3193, GSE5460, GSE2109, GSE10843, } \\
\text { GSE5720, GSE9014, GSE7390, GSE5764, GSE1561, } \\
\text { GSE5949, GSE3971, GSE1379 }\end{array}$ \\
\hline NR2F6 & EAR2 & & $\begin{array}{l}\text { GSE2109, GSE10843, GSE3971, GSE5364, GSE10087, } \\
\text { GSE1561, GSE3193, GSE3744, GSE5460, GSE1477, } \\
\text { GSE4382, GSE5720, GSE1378, GSE5847 }\end{array}$ \\
\hline NR3B1 & $\mathrm{ERR} \alpha$ & $\begin{array}{l}\text { Isoflavones, DES, } \\
\text { chlordane }\end{array}$ & $\begin{array}{l}\text { GSE3971, GSE2109, GSE10087, GSE10843, GSE7390, } \\
\text { GSE9014, GSE1561, GSE1477, GSE1378, GSE5764, } \\
\text { GSE5460 }\end{array}$ \\
\hline NR3B2 & $\mathrm{ERR} \beta$ & $\begin{array}{l}\text { Isoflavones, DES, } \\
\quad 4 \mathrm{HT}\end{array}$ & $\begin{array}{l}\text { GSE5364, GSE10843, GSE6861, GSE5460, GSE2109, } \\
\text { GSE1378, GSE9014, GSE1379, GSE5764 }\end{array}$ \\
\hline NR3B3 & $\mathrm{ERR} \gamma$ & $\begin{array}{l}\text { Isoflavones, DES, } \\
\quad 4 \mathrm{HT}\end{array}$ & $\begin{array}{l}\text { GSE2109, GSE9014, GSE1561, GSE5460, GSE7390, } \\
\text { GSE10087, GSE1379 }\end{array}$ \\
\hline NR4A1 & NGFI-B & & $\begin{array}{l}\text { GSE10843, GSE1477, GSE5364, GSE9014, GSE3281, } \\
\text { GSE5460, GSE2109 }\end{array}$ \\
\hline NR4A2 & NURR1 & & $\begin{array}{l}\text { GSE9014, GSE5460, GSE2109, GSE3281, GSE5364, } \\
\text { GSE3971, GSE7390 }\end{array}$ \\
\hline$N R 4 A 3$ & NOR1 & & $\begin{array}{l}\text { GSE2109, GSE1379, GSE5460, GSE3893, GSE5847, } \\
\text { GSE1561, GSE5720, GSE8977, GSE9014 }\end{array}$ \\
\hline NR5A1 & SF-1 & Phospholipids & GSE5460, GSE9014, GSE8977, GSE3744 \\
\hline NR5A2 & $\mathrm{LRH}-1$ & Phospholipids & $\begin{array}{l}\text { GSE2109, GSE5847, GSE5764, GSE8977, GSE5460, } \\
\text { GSE1561 }\end{array}$ \\
\hline$N R 6 A 1$ & GCNF & & $\begin{array}{l}\text { GSE10843, GSE5847, GSE5460, GSE1561, GSE2109, } \\
\text { GSE5764 }\end{array}$ \\
\hline
\end{tabular}

DES, diethylstilbestrol; 4HT, 4-hydroxytamoxifen.

${ }^{a}$ GSE identification numbers denote publicly available gene expression studies from gene expression omnibus (GEO). For each study, expression of the relevant nuclear receptor is significantly increased in breast cancer versus normal mammary tissue $(P \leq 0.05$, pair-wise $t$-test).

controversy is that orphan nuclear receptors like steroidogenic factor-1 (SF1, NR5A1) and hepatocyte nuclear factor-4 (HNF4, NR2A1 and NR2A2) have been shown to bind phospholipids and fatty acids respectively (Wisely et al. 2002, Li et al. 2005). However, because the physiological and/or functional relevance of these interactions remain unclear, SF1 and HNF4 are still considered to be orphan nuclear receptors.

\section{Nuclear receptor structure and function}

As a group, most nuclear receptors share a common, highly conserved domain structure (Fig. 1). At the amino-terminus, the activation function-1 (AF1) domain is a highly divergent region that assists in regulating the transcriptional activity of nuclear receptors independent from ligand binding (Kumar \& Litwack 2009). The AF1 domain is one of the two major sites for the binding of nuclear receptor 


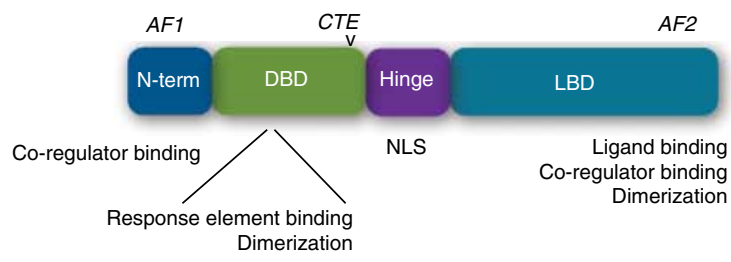

Figure 1 Nuclear receptor domain structure. AF1, activation function-1; DBD, DNA-binding domain; CTE, carboxy-terminal extension; NLS, nuclear localization sequence; LBD, ligandbinding domain; AF2, activation function-2.

coregulators, which include coactivator and corepressor proteins that can positively or negatively impact transcriptional activity respectively; it is also an important site of posttranslational modification, including phosphorylation and the addition of small ubiquitin-like modifier proteins (SUMOylation; Takimoto et al. 2003, Cheng et al. 2007, Zhang et al. 2007, Tamasi et al. 2008, Garza et al. 2010). Much less is known about the AF1 domain as compared with other regions of nuclear receptors. One key reason is that the AF1 domain has a high level of intrinsic disorder (ID; Kumar \& Litwack 2009), although this is not the only region of these receptors that is disordered (Krasowski et al. 2008). ID regions are characterized by amino acid sequences that are low in hydrophobicity and highly charged, leading to flexible, highly variable tertiary and quaternary protein structures. In general, all transcription factors are enriched in ID regions (Minezaki et al. 2006), and these appear to be critical for the regulation of protein-protein interactions (Dunker et al. 2005). In addition, the distribution of nuclear receptor coactivator proteins that can bind to the AF1 domain and regulate receptor function is tissue- and cell-type specific. It is now apparent that the differential expression and function of the entire group of nuclear receptor coregulators (coactivators and corepressors) in normal versus cancer tissue is a fundamental component of nuclear receptor regulation (Hall \& McDonnell 2005, O’Malley \& Kumar 2009).

The DBD of the nuclear receptor superfamily is defined by two cysteine-rich zinc finger motifs that permit binding of the receptor to DNA (Freedman et al. 1988). This region is also important in mediating the homo- and heterodimerization of nuclear receptors (Claessens \& Gewirth 2004). Proximal to the DBD is the flexible hinge region of the nuclear receptor, which typically contains the nuclear localization sequence (Claessens et al. 2001, Aschrafi et al. 2006, Carrigan et al. 2007). The hinge region is also a key site for posttranslational modifications (Sentis et al. 2005, Chen et al. 2006, Hwang et al. 2009).
Nuclear receptor DBDs contain a short stretch of amino acids downstream of the two zinc fingers known as the carboxy-terminal extension (CTE; Claessens \& Gewirth 2004). The CTE is present in ligand-regulated nuclear receptors like the estrogen receptors (ERs; Schultz et al. 2002), androgen receptor (AR; Schoenmakers et al. 1999), and the vitamin D receptor (Hsieh et al. 1999). However, orphan nuclear receptors such as estrogen-related receptor $\beta$ (ERR $\beta$, ESRRB, NR3B1) that bind a single half-site rely heavily on the A box of the CTE (which contains a conserved glycine-arginine motif) to permit DNA binding in the minor groove (Gearhart et al. 2003). In addition, residues $\mathrm{C}$-terminal to the $\mathrm{A}$ box form intramolecular interactions with the rest of the DBD; together, these interactions serve to stabilize the binding of ERR $\beta$ and several other orphan nuclear receptors to DNA.

The carboxy-terminal ligand-binding domain (LBD) and the AF2 domain are essential for the regulation of nuclear receptor transcriptional activity by mediating ligand and receptor interactions and coregulator binding; in some cases, these regions also participate in receptor dimerization (Chandra et al. 2008). Upon the engagement of natural or synthetic ligand, nuclear receptor LBDs undergo a significant conformational change that alters the orientation of several $\alpha$-helices and $\beta$-sheets, most notably the repositioning of helix 12 (H12) that comprises the AF2 domain (Wurtz et al. 1996). H12 repositioning uncovers a hydrophobic binding groove or charge clamp that recruits coregulator proteins containing an LXXLL motif (Westin et al. 1998), and the sum of these changes serves to significantly enhance nuclear receptor transcriptional activity.

In contrast to ligand-regulated nuclear receptors, the orphan nuclear receptors typically display constitutive transcriptional activity. While crystal structures for many orphan LBDs appear to be ligand-filled, some are still modulated by synthetic agonists and antagonists (Table 1). Thus, it remains possible that some of these receptors have natural ligands that have not yet been discovered. Even in the absence of ligand, H12 is often prepositioned for maximal activation, promoting interactions between the orphan nuclear receptor and its coactivators (Greschik et al. 2002, Flaig et al. 2005). It has also become increasingly clear that orphan nuclear receptors are particularly sensitive to the binding of coactivator proteins. Differential coregulator binding can directly affect, which DNA response elements are bound and activated (Gaillard et al. 2007), and modified coactivators that are selective for particular orphans can be designed to further explore the biology of these receptors (Gaillard et al. 2006, Stein et al. 2008). 
Benoit et al. (2006) have recently published a comprehensive review of all nuclear receptors currently classified as orphaned, summarizing what is known about their expression patterns, coregulatory molecules, validated transcriptional target genes, and any phenotypes associated with their perturbation in mice. Therefore, we will specifically focus on a review of the evidence supporting a role for orphan nuclear receptors in breast cancer pathogenesis and therapeutic response.

\section{Introduction to breast cancer}

The American Cancer Society estimates that in 2009, 178000 women were diagnosed with breast cancer, and over 40000 women died of breast cancer (Jemal et al. 2009), making it the second-most common cause of cancer-related death in women. Breast cancer is not a single disease; it is classified into multiple histological and molecular subtypes with diverse clinicopathological features and survival outcomes (Olopade et al. 2008, Orlando \& Brown 2009). The heterogeneity of breast cancer presents a major challenge for basic, translational, and clinical research. This is most often addressed by studying a combination of model systems, including tumor-derived cell culture models in vitro, xenograft models in immune-deficient mice, and genetically modified rodent models of mammary gland development and cancer. All these approaches are required because no single model is a perfect reflection of the diversity of human breast cancer (Clarke 1996). Recently, expression profiling of breast cancer clinical specimens has sought to uncover gene signatures that can classify tumors into various subgroups. The most widely utilized of these classification systems was developed by Sorlie et al. $(2001,2003)$ in which tumors are grouped into several classes, including Luminal A, Luminal B, ERBB2, basal-like, and normal-like. While signatures like these may ultimately prove useful in predicting outcome or response to specific therapies, they will require further refinement as additional subdivisions of these breast cancer subtypes (such as claudin low) are identified.

\section{Orphan nuclear receptors in rodent mammary gland biology and development}

Understanding mammary gland development and tumorigenesis in rats and mice has been instrumental in advancing the study of human breast cancer (Cardiff et al. 2000, Allred \& Medina 2008, Marcotte \& Muller 2008). However, little is known about the role(s) of specific orphan nuclear receptors in the developmental biology of the rodent mammary gland. This may be due to the fact that orphan nuclear receptor deletion in mice often has serious detrimental effects in multiple tissues that are manifested during embryogenesis or early in life, long before mammary glands develop beyond the rudimentary epithelial tree (Chen et al. 1994, Pereira et al. 1999, Collins et al. 2004, Moral et al. 2008). The creation of mammary gland-specific knockout or transgenic mice for key orphans will be required to explore their function in these tissues. Two orphan nuclear receptors have specifically been studied in the context of mouse mammary epithelial cell differentiation.

\section{DAX-1}

DAX-1 is an atypical member of the nuclear receptor superfamily because it lacks a DBD and relies on heterodimerization with other transcription factors that can bind DNA. These binding partners include a second orphan nuclear receptor, SF1, and it has been shown that DAX-1 can repress SF1-mediated stimulation of genes regulating steroid synthesis (Wang et al. 2001); DAX-1 can also repress the activity of ERs (Zhang et al. 2000). DAX-1 is strongly up-regulated in HC11 mouse mammary epithelial cells that have been induced to differentiate in vitro by withdrawing serum and growth factors prior to treatment with the lactogenic hormones insulin, dexamethasone, and prolactin (Faulds et al. 2004). It is the withdrawal of epidermal growth factor (EGF), and specifically, the resulting decrease in mitogen-activated protein kinase (MAPK) activity, which leads to DAX-1 induction (Helguero et al. 2006). Once induced, DAX-1 is enriched in the nucleus, and inhibits the transcriptional activity of ER $\alpha$ and ER $\beta$, as well as the proliferation of HC11 cells treated with ER $\alpha$ - and ER $\beta$-specific agonists. Finally, the expression of DAX-1 is significantly induced in the mammary glands of pseudopregnant and lactating 3-month-old C57BL/6 female mice as compared with virgin animals. Together, these data suggest that the lack of sensitivity of pregnant and lactating mammary glands to estrogen stimulation may be due to increased expression of the ER corepressor DAX-1 (Helguero et al. 2006).

\section{Small heterodimerization partner}

SHP, the other orphan nuclear receptor lacking a DBD, is also strongly induced during HC11 cell differentiation (Faulds et al. 2004). While SHP can serve as an ER corepressor (Johansson et al. 1999), its role in mammary epithelial cell differentiation remains to be elucidated. 


\section{Orphan nuclear receptors in breast cancer}

While mRNA for all 25 orphan nuclear receptors is significantly over-represented in breast cancer versus normal breast tissue in multiple gene expression microarray experiments in ONCOMINE and the Gene Expression Omnibus (Table 1; Rhodes et al. 2004, Barrett et al. 2009), the significance of only a handful of these receptors has been studied in breast cancer.

\section{Chicken ovalbumin upstream promoter transcription factors, EAR2}

Chicken ovalbumin upstream promoter transcription factor-1 (COUP-TFI, NR2F1), -2 (COUP-TFII, NR2F2), and V-erbA-related protein 2 (EAR2, NR2F6) are type III nuclear receptors that preferentially bind to direct DNA repeats as homodimers, although COUP-TFII and EAR2 can also heterodimerize (Avram et al. 1999). COUP-TFs can interact with DNA-responsive elements that are also shared with ER $\alpha$ and ER $\beta$; the consensus estrogen response element (ERE) is a perfect inverted repeat (GGTCAnnn-TGACC), but there are many genes with imperfect EREs or multiple ERE half-sites upstream of their transcriptional start sites. Both COUP-TFs have a high affinity for these ERE half-sites, while ER preferentially binds consensus EREs (Klinge et al. 1997), and COUP-TFs can inhibit 17ß-estradiol $\left(\mathrm{E}_{2}\right)$-induced, ER-mediated transcriptional activity by physically interacting with ER and disrupting ER/DNA binding. The COUP-TF/ER physical interaction is mediated by amino acid residues within the DBD and LBD of $\mathrm{ER}$, and conformational changes in these domains induced by ER/DNA-binding reduce COUP-TF/ER interactions (Klinge 1999). COUP-TFI has a higher affinity for ERE half-sites in the presence of $E_{2}$ and $E R$, and COUP-TFI inhibits $\mathrm{E}_{2}$-induced ERE activity. These data suggest that specific ligands and the specific sequence(s) of EREs influence the degree to which COUP-TFs activate gene transcription.

Nakshatri et al. (2000) showed that COUP-TFII mRNA expression is increased in ER-positive $(\mathrm{ER}+)$ MCF7, T47D, and ZR75-1 and in ER-negative (ER - ) MDA-MB-231 breast cancer cells, but reduced in ER MDA-MB-468 and SkBr3 breast cancer cells, as compared with the nontumorigenic mammary epithelial cell line MCF10A. Overexpression of COUP-TFII inhibits cell proliferation in MDA-MB-435 cells by delaying progression through the $\mathrm{G} 2 / \mathrm{M}$ cell cycle transition, which results from its induction of p21 and the subsequent inhibition of cdk2 activity. However, the more recent classification of MDA-MB-435 cells as melanoma (Rae et al. 2004) raises the issue of whether this mechanism of growth inhibition is maintained in breast cancer cell lines. This is further called into question by More et al. (2003) who, in contrast, show that COUP-TFII mRNA and protein expression are highest in $\mathrm{SkBr} 3$ and lowest in MCF7 cells. Furthermore, mitogenic signals such as EGF significantly induce COUP-TFII expression in MCF7 cells in a MAPKdependent manner. Antiproliferative agents such as oncostatin M (OSM) dramatically reduce COUP-TFII expression. However, neither EGF nor OSM have any effect on COUP-TFI expression or function.

\section{DAX-1}

DAX-1 is expressed in benign breast disease, carcinoma in situ, and invasive breast cancer (Conde et al. 2004), and is significantly more highly expressed in invasive lobular carcinoma than in benign tissues. In this study, expression and nuclear localization of DAX-1 is positively correlated with lymph node-positive status, while cytoplasmic and nuclear DAX-1 are both positively associated with AR expression.

\section{Estrogen-related receptor $\alpha$}

$\mathrm{ERR} \alpha$ (ESRRA, NR3B1) is the most-studied orphan nuclear receptor in the context of breast cancer (Horard \& Vanacker 2003, Ariazi \& Jordan 2006, Stein \& McDonnell 2006, Tremblay \& Giguere 2007, ESRRA, in Atlas of Genetics and Cytogenetics in Oncology and Haematology, available: http://atlasgeneticsoncology. org/Genes/ESRRAID44408ch11q13.html). Members of the NR3B or ERR family are classified as type IV nuclear receptors that can bind to the ERE, which it shares with ER $\alpha$ and $\mathrm{ER} \beta$, and the SF1 response element (SF1RE), which it shares with SF1 and liver receptor homolog-1 (LRH-1); this latter element is also referred to as the estrogen-related response element (ERRE). The role of ERR $\alpha$ in energy homeostasis and metabolism is well documented (Giguere 2008), and more recently, studies suggest that this orphan nuclear receptor is also involved in the regulation of bone mineral density (Delhon et al. 2009). In breast cancer, ERR $\alpha$ is the most abundantly expressed member of the ERR family. ERR $\alpha$ can induce expression of the estrogen-regulated gene TFF1 (pS2; Surowiak et al. 2006, Markićević et al. 2008), through its binding to an ERRE in the TFF1 promoter (Lu et al. 2001). Moreover, ER binds to multiple steroid hormone response element half sites (MHREs) in the ERR $\alpha$ promoter, inducing $E R R \alpha$ expression, and this activity is enhanced by the addition of estrogen (Liu et al. 2003).

$\mathrm{ERR} \alpha$ may play distinct roles in ER + versus ER breast cancer. ERR $\alpha$ activity at ERE sites is highly dependent on cell context, acting as a transcriptional 
activator in ER - cells but a repressor in ER + cells (Kraus et al. 2002), and ERR $\alpha$ expression is only positively associated with TFF1 expression in ERbreast tumors (Heck et al. 2009). Posttranslational modification of ERR $\alpha$ provides one potential explanation for these context-dependent activities. Phosphorylation of ERR $\alpha$ by the HER2/MAPK/AKT pathway is a critical determinant in the receptor's ability to recruit coactivator proteins and activate transcription from ERE sites in ER + cells (Ariazi et al. 2007). In breast tumors, ERR $\alpha$ mRNA expression is negatively correlated with ER + status but shows a strong positive correlation with HER2 expression (Ariazi et al. 2002). Phosphorylation can subsequently lead to SUMOylation of ERR $\alpha$, which also modulates its activity (Vu et al. 2007, Tremblay et al. 2008). Most recently, Wilson et al. (2010) have shown that ERR $\alpha$ acetylation by p300 coactivator-associated factor inhibits ERR $\alpha$ transcriptional activity, while histone deacetylase 8 (HDAC8) and a homolog of sirtuin 1 (Sirt1) can reverse acetylation and increase receptor binding to DNA.

Discerning the relevant estrogen signaling pathways controlled by ERR $\alpha$ versus ER is potentially challenging. However, two recent studies have convincingly shown that genes induced by ERR $\alpha$ in breast cancer cells have very little overlap with those transcribed in response to ER activation. First, using a variant of PPAR $\gamma$ coactivator-1 $\alpha$ (PGC-1 $\alpha$ ) engineered to selectively activate ERRs but not ER or other nuclear receptors, Stein et al. (2008) found that very few ERR $\alpha$-regulated genes are related to estrogen signaling. Instead, ERR $\alpha$ appears primarily to control oxidative stress signaling and aerobic metabolism (particularly key components of electron transport and the tricarboxylic acid cycle) in ER + MCF7 breast cancer cells; ERR $\alpha$ also induces the expression of vascular endothelial growth factor (Stein et al. 2009).

More recently, Deblois et al. (2009) have uncovered why the gene targets of ERR $\alpha$ and ER in breast cancer cells are so distinct. Using comparative genome-wide chromatin immunoprecipitation, they determined that the binding sites utilized by ERR $\alpha$ and ER, in the vast majority of cases, do not overlap. They did identify a group of genes $(n=212,18 \%$ of the total) that are targets of both receptors. However, while the promoter regions of some of these dual targets have distinct EREs and ERREs in close proximity, the majority of these coregulated genes are driven by an entirely novel DNA response element termed an ERRE/ERE, in which an ERRE (underlined) merges with a classical ERE (bold) (TCAAGGTCANNNTGACCT). These ERRE/ERE sites are only occupied by a single receptor (ERR $\alpha$ or ER) at a time.
In ER - MDA-MB-231 breast cancer cells, siRNA targeted to ERR $\alpha$ does not inhibit proliferation in vitro but does significantly reduce these cells' migratory ability and delays xenograft tumor growth (Stein et al. 2008). In contrast, Chisamore et al. (2009b) have shown that inhibiting ERR $\alpha$ signaling using a novel synthetic antagonist of the receptor (compound A; $N$-[(2Z)-3-(4,5-dihydro-1,3-thiazol-2-yl)-1,3-thiazolidin-2ylidene]-5Hdibenzo[a,d][7] annulen-5-amine), blocks cell proliferation in ER + (MCF7, T47D) and ER - (BT-20, MDA-MB-231) breast cancer cell lines in vitro. Compound $\mathrm{A}$ has no effect on $\mathrm{ERR} \alpha \mathrm{mRNA}$ expression, but abrogates ERR $\alpha$-mediated transcriptional activity in MCF7 cells and accelerates degradation of the receptor by the ubiquitin-proteasome pathway (Chisamore et al. 2009a). A different ERR $\alpha$ antagonist, XCT790, also inhibits MCF7 and MDA-MB-231 proliferation in vitro and tumor formation in nude mice (Bianco et al. 2009). Like compound A, XCT790 does not inhibit ERR $\alpha$ mRNA expression but instead enhances ERR $\alpha$ protein degradation; XCT790 also blocks interaction of ERR $\alpha$ with its coactivator PGC- $1 \alpha$ (Lanvin et al. 2007). These findings suggest that pharmacological inhibition of ERR $\alpha$ may represent a promising therapeutic approach, particularly in ER - breast cancer.

ERR $\alpha$ appears to integrate well with known breast tumor molecular subtypes (Sorlie et al. 2001). ERR $\alpha$ target genes are specifically enriched in the ERBB2 or HER2 cluster (Deblois et al. 2009). Greater than 80 ERR $\alpha$ targets have prognostic value in several independent datasets, and a subset of these has independent prognostic value beyond ER and ERBB2 status in multivariate analyses. Other ERR $\alpha$ target genes identified by Deblois et al., including GRB7 and ERBB2, are already incorporated into the OncotypeDX diagnostic test (Paik et al. 2004). Finally, gene expression analysis of distinct murine brain and bone metastases of a breast tumor line established from a patient with advanced breast cancer found that ERR $\alpha$, its coactivators PGC- $1 \alpha$ and PGC- $1 \beta$, and several known ERR target genes that control oxidative phosphorylation and the tricarboxylic acid cycle were selectively enriched in brain metastases.

\section{Estrogen-related receptor $\gamma$}

ERR $\gamma$ (ESRRG, NR3B3) shares 90\% sequence identity with the DBD, and $\sim 60 \%$ sequence identity with the LBD, of ERR $\alpha$ (Horard \& Vanacker 2003). Like ERR $\alpha, E R R \gamma$ is implicated in metabolism and cancer (Ariazi \& Jordan 2006, Giguere 2008, ESRRG, in Atlas of Genetics and Cytogenetics in Oncology and 
Haematology, available: http://atlasgeneticsoncology. org/Genes/ESRRGID45840ch1q41.html). However, the role of ERR $\gamma$ in the etiology of breast cancer remains unclear.

One of the more puzzling aspects of the relationship between ERR $\alpha$ and ERR $\gamma$ is that at first glance, they appear to have opposite prognostic value in breast cancer. The different associations arise from a study, in which 38 unselected breast tumors were compared to nine different populations of mammary epithelial cells (Ariazi et al. 2002). Within the tumor samples, ERR $\alpha$ mRNA expression correlates significantly with ER and progesterone receptor-negative $(\mathrm{PR}-)$ status, and with HER $2+$ status. ER -/PR - /HER $2+$ tumors are more aggressive than $\mathrm{ER}+/ \mathrm{PR}+$ tumors, leading to the conclusion that ERR $\alpha$ is a marker of poor clinical outcome. The ability of ERR $\alpha$ (Suzuki et al. 2004) and its target genes (Deblois et al. 2009) to function independently as poor prognostic factors have been subsequently confirmed. In direct contrast, breast tumors expressing ERR $\gamma$ are significantly more likely to be $\mathrm{ER}+$ and $\mathrm{PR}+$ (Ariazi et al. 2002). $\mathrm{ER}+/ \mathrm{PR}+$ status is, overall, a marker of good outcome. However, unlike ERR $\alpha, E R R \gamma$ has not been shown to have independent prognostic value, positive or negative, in any study. ERR $\gamma$ s association with good outcome remains linked to its overrepresentation in ER +/PR + tumors, not all of which have a good prognosis (see section on endocrine therapy below).

\section{Liver receptor homolog-1}

LRH-1 (NR5A2) is a type IV nuclear receptor that binds as a monomer to the SF1RE DNA response element (Fayard et al. 2004). LRH-1 is an important regulator of bile acid homeostasis, reverse cholesterol transport from peripheral tissues to the liver, and steroidogenesis; LRH-1 can bind C16 and C18 phospholipids such as phosphatidylglycerol and phosphatidylethanolamine (Ortlund et al. 2005). LRH-1 mRNA and protein expression is significantly elevated in breast tumors and their surrounding adipose tissue as compared with normal breast (Zhou et al. 2005, Miki et al. 2006). LRH-1 is positively associated with $\mathrm{ER}+, \mathrm{PR}+$, and $\mathrm{AR}$-positive $(\mathrm{AR}+)$ status, but negatively correlated with increased tumor stage, grade, and HER2 + status. Interestingly, LRH-1positive status is associated with improved survival in women with PR + breast cancer, but worse survival in women with $\mathrm{PR}-$ breast cancer. The establishment of LRH-1 as an ER target gene (Annicotte et al. 2005) has additional implications for endocrine therapy responsiveness in $\mathrm{ER}+$ breast cancer.

\section{Nerve growth factor-induced B, nuclear receptor-related 1 , and neuron-derived orphan receptor 1}

Nerve growth factor-induced B (NGFI-B, NR4A1; also known as Nur77 or testicular receptor 3 (TR3)), nuclear receptor-related 1 (NURR1, NR4A2), and neuron-derived orphan receptor 1 (NOR1, NR4A3) make up a group of closely related type IV nuclear receptors. A key feature of all three receptors is their apparent lack of a true ligand-binding pocket (Wang et al. 2003), although various diindolylmethanes (DIMs) have been shown to have agonist activity toward NGFI-B (Dae Cho et al. 2010). NGFI-B plays an interesting dual role in cell fate, functioning as a prosurvival factor when found in the nucleus but strongly inducing apoptosis when it translocates to the mitochondria, binds $\mathrm{Bcl}-2$, and promotes cytochrome $c$ release (Ferri \& Kroemer 2001, Moll et al. 2006). MCF7 cells express NGFI-B, and DIM treatment of this cell line inhibits cell proliferation and induces apoptosis (Chintharlapalli et al. 2005); NOR1 is also strongly induced early in the apoptotic process of MCF7 cells (Ohkubo et al. 2000).

\section{Rev-Erb $\alpha$}

V-erbA-related protein 1 (Rev-Erb $\alpha$, NR1D1; also known as EAR1) is a type IV nuclear receptor that regulates metabolism and circadian rhythm (Duez \& Staels 2009). Despite its orphan status, Rev-Erb $\alpha$ and the related Rev-Erb $\beta$ (NR1D2) are known to bind heme (Burris 2008). Rev-Erb $\alpha$ is localized to chromosome $17 \mathrm{q} 21$, a region that is frequently amplified in breast cancer; this region also harbors ERBB2, and Rev-Erb $\alpha$ is often coamplified and coexpressed with ERBB2 in breast tumors (Dressman et al. 2003, Chin et al. 2006). More recently, Davis et al. (2007) have reported that amplification of Rev-Erb $\alpha$ together with two other genes (SMARCE1 and BIRC5) functions as an accurate prognostic index independent of patient age or tumor stage in $\mathrm{ER}-/ \mathrm{PR}-$ breast tumors.

\section{Retinoic acid-related orphan receptor $\alpha$}

Retinoic acid-related orphan receptor $\alpha(\mathrm{ROR} \alpha$, NR1F1) is a monomeric type IV nuclear receptor that can, under some circumstances, bind to cholesterol or cholesterol sulfate (Kallen et al. 2004). ROR $\alpha$ is better known for its ability to regulate cerebellar development, the immune response, circadian rhythm, and resistance to atherosclerosis (Jetten 2004). However, several splice variants of this receptor are expressed in ER+ (MCF-7 and T47D) and ER - (BT-20, MDA-MB-231) 
breast cancer cells (Dai et al. 2001). ROR $\alpha$ is also localized to a well-known site of genomic instability (15q22.2), its expression is reduced in breast and other hormonally regulated tumors, and overexpression of $\mathrm{ROR} \alpha$ in MCF12F cells significantly inhibits their proliferation (Zhu et al. 2006).

\section{TR2 and TR4}

Human TR2 (NR2C1) and TR4 (NR2C2) are classified as type III nuclear receptors, although they do not exclusively form homodimers (Lee et al. 2002). Both TRs are generally considered to be transcriptional repressors; TR2 is implicated in preadipocyte proliferation (Gupta et al. 2007) and erythroid cell differentiation (Tanabe et al. 2007), while TR4 plays an important role in gluconeogenesis (Liu et al. 2007) and promyelocyte proliferation (Koritschoner et al. 2001). Both TR4 (Shyr et al. 2002) and TR2 (Hu et al. 2002) can repress ER transcriptional activity, and radiationstimulated p53 induction in MCF-7 cells downregulates TR2 expression (Lin \& Chang 1996).

\section{Orphan nuclear receptors and response to chemotherapy}

Several cytotoxic chemotherapies play a key role in the clinical management of locally advanced and/or metastatic breast cancer (Shajahan et al. 2008). Anthracyclines (e.g. doxorubicin) induce DNA damage by intercalating into DNA while also inhibiting the activity of topoisomerase II and inducing reactive oxygen species (ROS). Alkylating agents (e.g. cisplatin) also induce DNA damage, but do so by forming DNA adducts that block DNA synthesis. In contrast, antimetabolites (e.g. 5-fluorouracil, 5-FU) inhibit the enzyme thymidylate synthase, which normally produces thymidine $5^{\prime}$-monophosphate (dTMP) that is used in the synthesis of DNA. 5-FU can also affect mRNA translation or inhibit rRNA processing (Burger et al. 2010, Kudo et al.2010). Finally, two subclasses of antimicrotubule drugs are key inhibitors of tumor cell growth and inducers of tumor cell death by apoptosis and other mechanisms; the taxanes (docetaxel and paclitaxel) stabilize, while the Vinca alkaloids (vincristine and vinblastine) promote the destruction of the cellular microtubule network.

\section{Estrogen-related receptor $\alpha$}

There is some evidence that supports a role for ERR $\alpha$ in response to 5-FU-based chemotherapy. Uridine phosphorylase (UPase) is one of the essential enzymes required for metabolizing 5-FU (Maring et al. 2005).
UPase mRNA expression is positively regulated by $\mathrm{ERR} \alpha$ and the nuclear receptor coactivator PGC- $1 \alpha$ (Kong et al. 2009b). Specifically, PGC-1 $\alpha /$ ERR $\alpha$ complexes bind to the UPase promoter, and the ability of PGC- $1 \alpha$ to induce UPase transcription in MCF7 cells is abrogated by the ERR $\alpha$-specific small molecule inhibitor XCT790. Moreover, PGC- $1 \alpha$ overexpression sensitizes $\mathrm{SkBr} 3$ breast cancer cells to cell death induced by $5-\mathrm{FU}$, and this sensitization is also reversed by XCT790. These data suggest that the coexpression of PGC- $1 \alpha$ and ERR $\alpha$ in breast tumors may indicate enhanced sensitivity to 5-FU-containing treatment regimens.

In contrast, this same group has shown that in multidrug-resistant HepG2 cells overexpressing the MDR1 drug transporter (R-HepG2), XCT790 alone can inhibit growth, alter mitochondrial membrane potential, and stimulate the production of ROS that ultimately induce caspase-dependent apoptosis (Wu et al. 2009). R-HepG2 cells are resistant to both doxorubicin and paclitaxel; however, while XCT790 can synergistically restore paclitaxel sensitivity, it has neither an additive nor synergistic effect on doxorubicin response. The authors propose that XCT790s ability to induce ROS is better complemented by paclitaxel's stabilization of the microtubule network (thus leading to synergistic inhibition of cell growth). Since doxorubicin already can induce ROS, additive or synergistic interactions are not seen because XCT790 and doxorubicin affect similar downstream pathways. It is not immediately clear whether XCT790 might have similar effects on doxorubicin and/or paclitaxel response in multidrug-resistant breast cancer cells.

\section{Nuclear receptor-related 1}

One of the NR4 orphan nuclear receptors, NURR1, has been implicated in resistance to doxorubicin. Overexpression of NURR1 significantly decreases the expression of a proapoptotic member of the BCL2 gene family (BAX), while protecting cells in culture from apoptosis following doxorubicin treatment (Zhang et al. 2009). The DBD of NURR1 was subsequently found to interact with the C-terminus of the tumor suppressor p53. NURR1/p53 interaction prevents oligomerization of $\mathrm{p} 53$, attenuating the induction of p53 target genes (which include BAX). While these studies were not performed in breast cancer cells, BAX is important in doxorubicin sensitivity in MCF7 breast cancer cells (Kong et al. 2009a) and human breast tumors (Parton et al. 2002, Chintamani et al. 2004), suggesting that NURR1 could play an important role in this context. 


\section{Orphan nuclear receptors and response to endocrine or hormonal therapy}

ER- $\alpha$-positive $(\mathrm{ER}+)$ breast tumors comprise $\sim 70 \%$ of annually diagnosed breast cancer cases (Jemal et al. 2009). Adjuvant or neoadjuvant endocrine therapy is among the least toxic, best tolerated, and most effective therapies available to patients with ER + breast cancer. There are currently three major classes of endocrine therapy used in the clinic: selective ER modulators (SERMs), selective ER downregulators (SERDs), and aromatase inhibitors (AIs; Crago et al. 2010).

The prototypical SERM is the triphenylethylene tamoxifen, which competes with estrogen $\left(E_{2}\right)$ for binding to ER and in breast tissue is most often an antagonist; however, in bone, brain, and endometrial tissues, tamoxifen can act as a partial agonist (Clarke et al. 2001). In contrast, Fulvestrant (ICI 182780 , or Faslodex) functions as a SERD, a pure antagonist of ER in all tissues that compete for $\mathrm{E}_{2}$ binding and accelerates degradation of the receptor via the ubiquitinproteasome pathway. Steroidal and nonsteroidal AIs (exemestane, letrozole, and anastrazole) are inhibitors of the cytochrome P450 family member CYP19A1 (aromatase) that catalyzes the conversion of testosterone to $\mathrm{E}_{2}$, therefore depriving $\mathrm{ER}+$ breast tumors of growth-stimulatory estrogen signaling (Santen et al. 2009). Tamoxifen is effective in the treatment of premenopausal and postmenopausal breast cancer patients. However, AIs are only indicated for use in postmenopausal women with breast cancer, where the major site of estrogen synthesis has shifted from the ovaries to the adrenal gland and adipose tissue.

As successful as each of these classes of endocrine therapies has been in the treatment of ER + breast cancer, resistance to tamoxifen, fulvestrant, and/or AIs is a significant and widespread clinical problem (Riggins et al. 2005, 2007, Buzdar 2008, Macedo et al. 2009, Musgrove \& Sutherland 2009). The proposed mechanisms of endocrine resistance are varied, and can include ER downregulation, silencing, or mutation, ER posttranslational modifications, changes in the expression profile(s) of nuclear receptor coregulators, and altered expression of key networks of growth factor signaling and/or apoptosis. Importantly, several orphan nuclear receptors have demonstrated potential to play important direct or indirect roles in endocrine therapy response and resistance.

\section{Chicken ovalbumin upstream promoter transcription factors}

Like the conflicting effects of the COUP-TFs on cell proliferation (Nakshatri et al. 2000, Moré et al. 2003), results from studies of the role(s) of these receptors in tamoxifen resistance are also contradictory.
A significant decrease in COUP-TFII protein expression is observed in three different MCF7-derived resistance models. Inhibition of COUP-TFII by siRNA in sensitive MCF7 cells prevents tamoxifen-induced growth inhibition (Riggs et al. 2006). However, COUP transcription factors have been shown to enhance ER transcriptional activity by forming tight homodimer complexes (Métivier et al. 2002). These physical complexes increase the affinity of ER for MAPK, resulting in increased ER phosphorylation at serine 118 and enhanced ER transcriptional activity. Thus, under certain circumstances, overexpression of COUP-TFs might negate the inhibitory effects of tamoxifen on ER. Moreover, overexpression of COUP-TFI has been shown to stimulate MCF7 cell growth and migration, via an ER-dependent pathway, by selectively up-regulating genes involved in cell proliferation; these effects are seen in the presence and the absence of $\mathrm{E}_{2}$ (Le Dily et al. 2008). Discerning the true role of COUP-TFI and COUP-TFII in ER signaling and endocrine resistance will require further study to clarify their seemingly conflicting activities.

\section{DAX-1}

The ability of DAX-1 to function as a corepressor for ER (Zhang et al. 2000) has potentially significant implications for responsiveness to antiestrogens. However, more is known about the role of DAX-1 in estrogen synthesis through its negative regulation of aromatase mRNA expression in ovarian granulosa cells (Gurates et al. 2003) and endometrial cells (Gurates et al. 2002); its family member SHP has also been shown to inhibit aromatase expression (Kovacic et al. 2004). In contrast, deletion of DAX-1 in male mice significantly upregulates aromatase expression (Wang et al. 2001). To our knowledge, there have been no studies of DAX-1 in the peripheral and breast adipose tissues of women with breast cancer. Given that these sites are the major source of estrogen synthesis in postmenopausal women (Macciò et al. 2009), and that DAX-1 expression is significantly higher in preadipocytes than in mature adipose tissue (Kim et al. 2008), studies of DAX-1 in the context of AI-responsive and -resistant breast cancer could be informative.

\section{Estrogen-related receptor $\alpha$}

Although the expression of ERR $\alpha$ in breast tumors is inversely associated with ER + status (Ariazi et al. 2002), there are a number of ways in which this orphan nuclear receptor might affect endocrine therapy responsiveness. First, a small subset of ER + breast cancers also expresses HER2. HER2-dependent 
phosphorylation allows ERR $\alpha$ to activate transcription from EREs (Ariazi et al. 2007), potentially bypassing the inhibitory effects of SERMs and SERDs. Given that addition of the HER2 inhibitors trastuzumab or gefitinib to endocrine therapy appears to significantly improve disease-free survival in women with $\mathrm{ER}+$ / HER2 + breast cancer (Buzdar 2009, Johnston 2009), the contribution of ERR $\alpha$ to endocrine resistance, when it is expressed in ER +/HER2 + tumors, should be explored further. In addition, at least two genes identified as ERR $\alpha$ targets with prognostic value in breast cancer (Deblois et al. 2009) are known effectors of tamoxifen resistance. GRB7 is a breast cancer antiestrogen resistance gene that can confer estrogen independence and antiestrogen resistance to breast cancer cell lines (van Agthoven et al. 2009b), and has independent prognostic value in tamoxifen-resistant breast cancer patients (van Agthoven et al. 2009a). Cyclin E1 (CCNE1), particularly the low-molecular weight forms of this cell cycle regulator, has also been implicated in tamoxifen resistance (Dhillon \& Mudryj 2002, Akli et al. 2004).

Alternatively, the ERR $\alpha$-specific inhibitor XCT790 has been shown to enhance SERD activity by accelerating fulvestrant-dependent degradation of ER in MCF7 breast cancer cells (Lanvin et al. 2007). The mechanism by which this occurs is not entirely clear; the extent of ERR $\alpha$ degradation in response to XCT790 is greater in ER- MDA-MB-231 cells than ER+ MCF7 cells, but when ER expression is restored in MDA-MB-231 cells, the ability of XCT790 to induce ERR $\alpha$ degradation is unchanged. Furthermore, transfection of MCF7 cells (which express both ER and ERR $\alpha$ ) with siRNA specific for each receptor does not lead to enhanced sensitivity of the other receptor to its antagonist. The authors ultimately proposed that ER and ERR $\alpha$ heterodimerize in breast cancer cells in a way that confers protection to each receptor from protein degradation induced by their specific antagonists, and suggest that XCT790 may therefore be useful in combination with fulvestrant to improve endocrine therapy response in the clinic (Lanvin et al. 2007). However, heterodimerization of ER and ERR $\alpha$ has not been convincingly demonstrated, so this mode of action currently seems somewhat unlikely. Finally, in breast cancer cells, ERR $\alpha$ forms a transcriptional complex on aromatase promoters I.3 and II with the nuclear receptor coactivators proline, glutamate, and leucine-rich protein 1 (PELP1) and proline-rich nuclear receptor coactivator 2 (PNRC2), thereby inducing aromatase expression and promoting localized estrogen synthesis (Rajhans et al. 2008).

\section{Estrogen-related receptor $\gamma$}

As discussed above, the expression of ERR $\gamma$ in breast tumors is associated with ER + and PR + status (Ariazi et al. 2002). This has led to the notion that ERR $\gamma$ is a marker of good prognosis and response to endocrine therapy. However, $30 \%$ of women have $\mathrm{ER}+/ \mathrm{PR}+$ breast tumors that are intrinsically (de novo) resistant to tamoxifen, and when initially responsive patients present with recurrent, endocrine-resistant disease, in most cases, these recurrent/resistant tumors retain ER expression (Riggins et al. 2005). Therefore, genes that are primarily expressed in ER + breast tumors are not necessarily good prognostic factors. A clear example is X-box-binding protein 1 (XBP1), a key mediator of the unfolded protein response (Feldman et al. 2005). XBP1 is coexpressed with ER in breast tumors (Lacroix \& Leclercq 2004, Tozlu et al. 2006, Wilson \& Giguère 2008). However, XBP1 is an ER coactivator that induces ligand-independent activation of the receptor (Ding et al. 2003a,b, Fang et al. 2004), XBP1 upregulation is evident in some antiestrogen resistant cells (Gu et al. 2002), and its ectopic overexpression leads to tamoxifen resistance and estrogen independence in multiple ER + breast cancer cell lines (Gomez et al. 2007). The presence of spliced or active XBP1 in breast tumors is also significantly associated with poor clinical response to tamoxifen (Davies et al. 2008).

We have shown that ERR $\gamma$ can play an important functional role in the acquisition of tamoxifen resistance by breast cancer cell lines derived from invasive lobular carcinoma (Riggins et al. 2008). The tamoxifen-resistant variant of the SUM44 breast cancer cell line (Ethier et al. 1993), LCCTam, expresses significantly more ERR $\gamma$ mRNA and protein, and knockdown of this orphan nuclear receptor restores tamoxifen-mediated growth inhibition. In contrast, ectopic overexpression of ERR $\gamma$ cDNA independently induces tamoxifen resistance in SUM44 cells and another model of ILC, MDA-MB134 VI (Reis-Filho et al. 2006). The mechanism by which ERR $\gamma$ mediates tamoxifen resistance is under active investigation. As discussed above, ERR $\gamma$ can induce gene transcription from ERE and ERRE sites, and one of the more active metabolites of tamoxifen (4-hydroxytamoxifen, 4HT) inactivates ERR $\gamma$ with respect to transcription from both of these response elements (Greschik et al. 2004). However, studies in nonbreast cancer cell lines show that in the presence of 4HT, ERR $\gamma$ can potently activate transcription from activator protein-1 (AP1) sites (Huppunen et al. 2004). We subsequently demonstrated that the resistant LCCTam cells have significantly higher AP1 activity 
in the presence of tamoxifen, and that a peptide inhibitor of AP1 effectively restores tamoxifen responsiveness (Riggins et al. 2008). Because the full compliment of endogenous ERR $\gamma / \mathrm{AP} 1$ target genes are unknown, current studies are focused on identifying these targets in order to understand how this orphan nuclear receptor contributes to tamoxifen resistance.

Importantly, ERR $\gamma$ s function in tamoxifen resistance may not be restricted to ILC. We have recently found that ERR $\gamma$ mRNA expression is significantly increased in the MCF7/RR model (Butler \& Fontana 1992) of tamoxifen resistance (O Z Maniya, M M Mazzotta, and R B Riggins, unpublished observations). This is supported by in silico reanalysis of gene expression microarray data from a study of 60 women diagnosed with ER + breast cancer who were treated only with tamoxifen (Ma et al. 2004). Pretreatment mRNA levels of ERR $\gamma$ are significantly elevated in tumors from breast cancer patients who recurred within 5 years of tamoxifen therapy compared with those from breast cancer patients who did not recur (Fig. 2), and $\sim 80 \%$ of this patient population had invasive ductal carcinoma. Further studies are needed to better understand how ERR $\gamma$ functions in the full spectrum of tamoxifen-resistant, ER + breast cancer.

\section{Liver receptor homolog-1}

LRH-1 strongly induces aromatase expression from promoter II in preadipocytes (Clyne et al. 2002) and breast adipose tissue (Clyne et al. 2004), and its ability to do so can be inhibited by SHP (Kovacic et al. 2004). The presence of higher levels of LRH-1 mRNA in breast tumors and their surrounding adipose tissue,

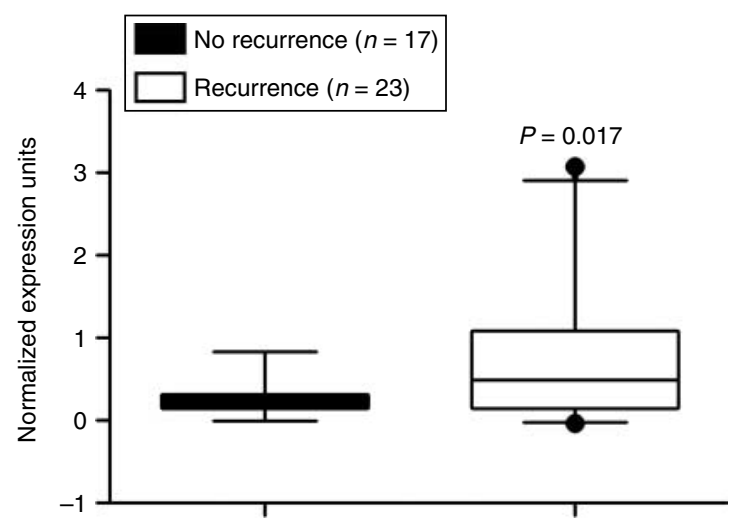

Figure 2 Elevated ERR $\gamma$ expression in tamoxifen-resistant breast tumors. Reanalysis of gene expression microarray data from Ma et al. (2004) shows that pretreatment ERR $\gamma$ expression is significantly increased in the tumors of breast cancer patients who recurred within 5 years of tamoxifen therapy $(P=0.017$, Mann-Whitney rank sum test). as compared with normal breast, mirrors the expression of aromatase in these tissues (Zhou et al. 2005). More recent studies show that cooperation between LRH-1 and GATA transcription factors (Bouchard et al. 2005) or PGC-1 $\alpha$ (Safi et al. 2005) strongly induces aromatase expression.

As stated above, LRH-1 is an ER target gene (Annicotte et al. 2005), and tumoral LRH-1 expression is associated with improved survival in women with $\mathrm{PR}+$ breast cancer but worse survival in women with PR - breast cancer (Miki et al. 2006). Together with its demonstrated ability to induce transcription of aromatase, these data suggest that LRH-1 may be a marker of intact aromatase/estrogen/ER signaling that indicates improved sensitivity to endocrine therapies such as tamoxifen or an AI. Two clinical studies provide some support for this. Using specimens from the P025 trial in which letrozole was compared with tamoxifen, women with PR + breast tumors that also expressed aromatase trended toward having improved time to progression when treated with letrozole (Lykkesfeldt et al. 2009). In the P024 trial that also compared letrozole to tamoxifen, increased aromatase expression at baseline was significantly associated with improved relapse-free survival in multivariate analyses (Ellis et al. 2009).

\section{Retinoic acid-related orphan receptor $\alpha$}

$\mathrm{ROR} \alpha$ has also been shown to induce aromatase expression by enhancing its transcription from promoter I.4, and can significantly increase aromatase activity in ER + T47D and MCF7 breast cancer cells (Odawara et al. 2009). This study also showed that ROR $\alpha$ and aromatase expression are positively correlated in breast cancer clinical specimens. ROR $\alpha$ deletion in mice suggests an even broader role for this gene in regulating multiple components of steroidogenesis other than aromatase, including several sulfotransferases and hydroxysteroid dehydrogenases (Kang et al. 2007). However, a different study reports that ROR $\alpha$ expression is reduced in breast cancer compared with normal tissue (Zhu et al. 2006), so it is still unclear how this orphan nuclear receptor functions in breast tumors or modulates endocrine therapy response.

\section{Summary and perspectives}

The field of breast cancer research has much to gain from the continued study of orphan nuclear receptors. Many of these unique transcription factors have the potential to transform our understanding of how tumorigenesis is integrated with fundamental 
physiological processes such as metabolism, regulation of circadian rhythm, and obesity (Sahar \& Sassone-Corsi 2009, Froy 2010). We also have a great deal to learn about how orphan nuclear receptors function in normal mammary tissue in mice and humans. Exploring these unresolved areas of orphan nuclear receptor biology could ultimately lead to discoveries that will improve our ability to diagnose, treat, and prevent breast cancer.

\section{Declaration of interest}

The authors declare that they have no conflict of interest that could be perceived as prejudicing the impartiality of the research reported.

\section{Funding}

This work was generously supported by grants from Susan G Komen for the Cure (KG090187 to R B Riggins; KG090245 to R Clarke), the Department of Defense Breast Cancer Research Program (BC073977 to R Clarke), and the Public Health Service (R03-CA142009 to R B Riggins; R01CA131465 and R21-CA139246 to R Clarke). This project has also been funded in part with Federal funds from the National Cancer Institute, National Institutes of Health, under Contract No. HHSN261200800001E to R Clarke. The content of this publication does not necessarily reflect the views or policies of the Department of Health and Human Services, nor does mention of trade names, commercial products, or organizations imply endorsement by the US Government.

\section{Author contribution statement}

R B Riggins and R Clarke developed the original idea and outline, while all authors made significant contributions to the writing and editing of this manuscript.

\section{Acknowledgements}

We sincerely thank all members of the Clarke and Riggins labs, as well as the broader Lombardi Comprehensive Cancer Center community, for their insight and helpful comments.

\section{References}

van Agthoven T, Sieuwerts A, Meijer-van Gelder M, Look M, Smid M, Veldscholte J, Sleijfer S, Foekens J \& Dorssers L $2009 a$ Relevance of breast cancer antiestrogen resistance genes in human breast cancer progression and tamoxifen resistance. Journal of Clinical Oncology 27 542-549.

van Agthoven T, Veldscholte J, Smid M, van Agthoven T,

Vreede L, Broertjes M, de Vries I, de Jong D, Sarwari R \& Dorssers L $2009 b$ Functional identification of genes causing estrogen independence of human breast cancer cells. Breast Cancer Research and Treatment 114 23-30.
Akli S, Zheng P, Multani A, Wingate H, Pathak S, Zhang N, Tucker S, Chang S \& Keyomarsi K 2004 Tumor-specific low molecular weight forms of cyclin $\mathrm{E}$ induce genomic instability and resistance to p21, p27, and antiestrogens in breast cancer. Cancer Research 64 3198-3208.

Allred D \& Medina D 2008 The relevance of mouse models to understanding the development and progression of human breast cancer. Journal of Mammary Gland Biology and Neoplasia 13 279-288.

Annicotte J, Chavey C, Servant N, Teyssier J, Bardin A, Licznar A, Badia E, Pujol P, Vignon F, Maudelonde T et al. 2005 The nuclear receptor liver receptor homolog-1 is an estrogen receptor target gene. Oncogene $\mathbf{2 4}$ 8167-8175.

Ariazi EA \& Jordan VC 2006 Estrogen-related receptors as emerging targets in cancer and metabolic disorders. Current Topics in Medicinal Chemistry 6 203-215.

Ariazi EA, Clark GM \& Mertz JE 2002 Estrogen-related receptor alpha and estrogen-related receptor gamma associate with unfavorable and favorable biomarkers, respectively, in human breast cancer. Cancer Research 62 6510-6518.

Ariazi EA, Kraus RJ, Farrell ML, Jordan VC \& Mertz JE 2007 Estrogen-related receptor $\alpha 1$ transcriptional activities are regulated in part via the ErbB2/HER2 signaling pathway. Molecular Cancer Research 5 71-85.

Aschrafi A, Meindl N, Firla B, Brandes R \& Steinhilber D 2006 Intracellular localization of RORalpha is isoform and cell line-dependent. Biochimica et Biophysica Acta 1763 805-814.

Avram D, Ishmael J, Nevrivy D, Peterson V, Lee S, Dowell P \& Leid M 1999 Heterodimeric interactions between chicken ovalbumin upstream promoter-transcription factor family members ARP1 and ear2. Journal of Biological Chemistry 274 14331-14336.

Barrett T, Troup D, Wilhite S, Ledoux P, Rudnev D, Evangelista C, Kim I, Soboleva A, Tomashevsky M, Marshall K et al. 2009 NCBI GEO: archive for highthroughput functional genomic data. Nucleic Acids Research 37 D885-D890.

Benoit G, Malewicz M \& Perlmann T 2004 Digging deep into the pockets of orphan nuclear receptors: insights from structural studies. Trends in Cell Biology 14 369-376.

Benoit G, Cooney A, Giguere V, Ingraham H, Lazar M, Muscat G, Perlmann T, Renaud J, Schwabe J, Sladek F et al. 2006 International Union of Pharmacology. LXVI. Orphan nuclear receptors. Pharmacological Reviews 58 798-836.

Bianco S, Lanvin O, Tribollet V, Macari C, North S \& Vanacker J 2009 Modulating estrogen receptor-related receptor-alpha activity inhibits cell proliferation. Journal of Biological Chemistry 284 23286-23292.

Bouchard M, Taniguchi H \& Viger R 2005 Protein kinase A-dependent synergism between GATA factors and the nuclear receptor, liver receptor homolog-1, regulates human aromatase (CYP19) PII promoter activity in breast cancer cells. Endocrinology 146 4905-4916. 
Burger K, Mühl B, Harasim T, Rohrmoser M, Malamoussi A, Orban M, Kellner M, Gruber-Eber A, Kremmer E, Hölzel M et al. 2010 Chemotherapeutic drugs inhibit ribosome biogenesis at various levels. Journal of Biological Chemistry 285 12416-12425.

Burris T 2008 Nuclear hormone receptors for heme: REV-ERBalpha and REV-ERBbeta are ligand-regulated components of the mammalian clock. Molecular Endocrinology 22 1509-1520.

Burris T, Guo W \& McCabe E 1996 The gene responsible for adrenal hypoplasia congenita, DAX-1, encodes a nuclear hormone receptor that defines a new class within the superfamily. Recent Progress in Hormone Research 51 241-259.

Butler WB \& Fontana JA 1992 Responses to retinoic acid of tamoxifen-sensitive and -resistant sublines of human breast cancer cell line MCF-7. Cancer Research 52 6164-6167.

Buzdar A 2008 Fulvestrant - a novel estrogen receptor antagonist for the treatment of advanced breast cancer. Drugs of Today 44 679-692.

Buzdar A 2009 Role of biologic therapy and chemotherapy in hormone receptor- and HER2-positive breast cancer. Annals of Oncology 20 993-999.

Cardiff RD, Anver MR, Gusterson BA, Hennighausen L, Jensen RA, Merino MJ, Rehm S, Russo J, Tavassoli FA, Wakefield LM et al. 2000 The mammary pathology of genetically engineered mice: the consensus report and recommendations from the Annapolis meeting. Oncogene 19 968-988.

Carrigan A, Walther R, Salem H, Wu D, Atlas E, Lefebvre Y \& Haché R 2007 An active nuclear retention signal in the glucocorticoid receptor functions as a strong inducer of transcriptional activation. Journal of Biological Chemistry 282 10963-10971.

Chandra V, Huang P, Hamuro Y, Raghuram S, Wang Y, Burris T \& Rastinejad F 2008 Structure of the intact PPAR-gamma-RXR-alpha nuclear receptor complex on DNA. Nature 456 350-356.

Chen W, Manova K, Weinstein D, Duncan S, Plump A, Prezioso V, Bachvarova R \& Darnell JJ 1994 Disruption of the HNF-4 gene, expressed in visceral endoderm, leads to cell death in embryonic ectoderm and impaired gastrulation of mouse embryos. Genes and Development 8 2466-2477.

Chen M, Bradley M, Beaven S \& Tontonoz P 2006 Phosphorylation of the liver $\mathrm{X}$ receptors. FEBS Letters $5804835-4841$.

Cheng J, Zhang C \& Shapiro DJ 2007 A functional serine 118 phosphorylation site in estrogen receptor-alpha is required for down-regulation of gene expression by 17 beta-estradiol and 4-hydroxytamoxifen. Endocrinology 148 4634-4641.

Chin K, DeVries S, Fridlyand J, Spellman PT, Roydasgupta R, Kuo WL, Lapuk A, Neve RM, Qian Z, Ryder T et al. 2006 Genomic and transcriptional aberrations linked to breast cancer pathophysiologies. Cancer Cell 10 529-541.
Chintamani C, Singhal V, Singh J, Lyall A, Saxena S \& Bansal A 2004 Is drug-induced toxicity a good predictor of response to neo-adjuvant chemotherapy in patients with breast cancer? - a prospective clinical study. BMC Cancer 448.

Chintharlapalli S, Burghardt R, Papineni S, Ramaiah S, Yoon K \& Safe S 2005 Activation of Nur77 by selected 1,1-bis( $3^{\prime}$-indolyl)-1-(p-substituted phenyl)methanes induces apoptosis through nuclear pathways. Journal of Biological Chemistry 280 24903-24914.

Chisamore M, Cunningham M, Flores O, Wilkinson H \& Chen J 2009a Characterization of a novel small molecule subtype specific estrogen-related receptor alpha antagonist in MCF-7 breast cancer cells. PLoS ONE 4 e5624.

Chisamore M, Wilkinson H, Flores O \& Chen J 2009b Estrogen-related receptor-alpha antagonist inhibits both estrogen receptor-positive and estrogen receptor-negative breast tumor growth in mouse xenografts. Molecular Cancer Therapeutics 8 672-681.

Claessens F \& Gewirth DT 2004 DNA recognition by nuclear receptors. Essays in Biochemistry 40 59-72.

Claessens F, Verrijdt G, Schoenmakers E, Haelens A, Peeters B, Verhoeven G \& Rombauts W 2001 Selective DNA binding by the androgen receptor as a mechanism for hormone-specific gene regulation. Journal of Steroid Biochemistry and Molecular Biology 76 23-30.

Clarke R 1996 Animal models of breast cancer: their diversity and role in biomedical research. Breast Cancer Research and Treatment 39 1-6.

Clarke R, Leonessa F, Welch JN \& Skaar TC 2001 Cellular and molecular pharmacology of antiestrogen action and resistance. Pharmacological Reviews 53 25-71.

Clyne C, Speed C, Zhou J \& Simpson E 2002 Liver receptor homologue-1 (LRH-1) regulates expression of aromatase in preadipocytes. Journal of Biological Chemistry 277 20591-20597.

Clyne C, Kovacic A, Speed C, Zhou J, Pezzi V \& Simpson E 2004 Regulation of aromatase expression by the nuclear receptor LRH-1 in adipose tissue. Molecular and Cellular Endocrinology 215 39-44.

Collins L, Lee Y, Heinlein C, Liu N, Chen Y, Shyr C, Meshul C, Uno H, Platt K \& Chang C 2004 Growth retardation and abnormal maternal behavior in mice lacking testicular orphan nuclear receptor 4. PNAS 101 15058-15063.

Conde I, Alfaro J, Fraile B, Ruíz A, Paniagua R \& Arenas M 2004 DAX-1 expression in human breast cancer: comparison with estrogen receptors ER-alpha, ER-beta and androgen receptor status. Breast Cancer Research 6 R140-R148.

Crago A, Azu M, Tierney S \& Morrow M 2010 Randomized clinical trials in breast cancer. Surgical Oncology Clinics of North America 19 33-58.

Dae Cho S, Lee S, Chintharlapalli S, Abdelrahim M, Khan S, Yoon K, Kamat A \& Safe S 2010 Activation of nerve growth factor-induced $\mathrm{b} \alpha$ by methylene-substituted diindolylmethanes in bladder cancer cells induces apoptosis and inhibits tumor growth. Molecular Pharmacology 77 396-404. 
Dai J, Ram P, Yuan L, Spriggs L \& Hill S 2001

Transcriptional repression of RORalpha activity in human breast cancer cells by melatonin. Molecular and Cellular Endocrinology 176 111-120.

Davies M, Barraclough D, Stewart C, Joyce K, Eccles R, Barraclough R, Rudland P \& Sibson D 2008 Expression and splicing of the unfolded protein response gene XBP-1 are significantly associated with clinical outcome of endocrine-treated breast cancer. International Journal of Cancer 123 85-88.

Davis L, Harris C, Tang L, Doherty P, Hraber P, Sakai Y, Bocklage T, Doeden K, Hall B, Alsobrook J et al. 2007 Amplification patterns of three genomic regions predict distant recurrence in breast carcinoma. Journal of Molecular Diagnostics 9 327-336.

Deblois G, Hall J, Perry M, Laganière J, Ghahremani M, Park M, Hallett M \& Giguère V 2009 Genome-wide identification of direct target genes implicates estrogenrelated receptor alpha as a determinant of breast cancer heterogeneity. Cancer Research $696149-6157$.

Delhon I, Gutzwiller S, Morvan F, Rangwala S, Wyder L, Evans G, Studer A, Kneissel M \& Fournier B 2009 Absence of estrogen receptor-related-alpha increases osteoblastic differentiation and cancellous bone mineral density. Endocrinology 150 4463-4472.

Dhillon N \& Mudryj M 2002 Ectopic expression of cyclin E in estrogen responsive cells abrogates antiestrogen mediated growth arrest. Oncogene 21 4626-4634.

Ding L, Yan J, Zhu J, Zhong H, Lu Q, Wang Z, Huang C \& Ye Q 2003a Ligand-independent activation of estrogen receptor alpha by XBP-1. Nucleic Acids Research 31 5266-5274.

Ding LH, Ye QN, Zhu JH, Yan JH, Zhong HJ, Wang ZH \& Huang CF 2003b XBP-1 enhances the transcriptional activity of estrogen receptor alpha. Sheng Wu Hua Xиe Yu Sheng Wu Wu Li Xue Bao Acta Biochimica et Biophysica Sinica 35 829-833.

Dressman MA, Baras A, Malinowski R, Alvis LB, Kwon I, Walz TM \& Polymeropoulos MH 2003 Gene expression profiling detects gene amplification and differentiates tumor types in breast cancer. Cancer Research $\mathbf{6 3}$ 2194-2199.

Duez H \& Staels B 2009 Rev-erb-alpha: an integrator of circadian rhythms and metabolism. Journal of Applied Physiology 107 1972-1980.

Dunker AK, Cortese MS, Romero P, Iakoucheva LM \& Uversky VN 2005 Flexible nets. The roles of intrinsic disorder in protein interaction networks. FEBS Journal 272 5129-5148.

Ellis M, Miller W, Tao Y, Evans D, Chaudri Ross H, Miki Y, Suzuki T \& Sasano H 2009 Aromatase expression and outcomes in the P024 neoadjuvant endocrine therapy trial. Breast Cancer Research and Treatment 116 371-378.

Ethier SP, Mahacek ML, Gullick WJ, Frank TS \& Weber BL 1993 Differential isolation of normal liminal mammary epithelial cells and breast cancer cells from primary and metastatic sites using selective media. Cancer Research 53 627-635.

Fang Y, Yan J, Ding L, Liu Y, Zhu J, Huang C, Zhao H, Lu Q, Zhang X, Yang X et al. 2004 XBP-1 increases ERalpha transcriptional activity through regulation of large-scale chromatin unfolding. Biochemical and Biophysical Research Communications 323 269-274.

Faulds M, Olsen H, Helguero L, Gustafsson J \& Haldosén L 2004 Estrogen receptor functional activity changes during differentiation of mammary epithelial cells. Molecular Endocrinology 18 412-421.

Fayard E, Auwerx J \& Schoonjans K 2004 LRH-1: an orphan nuclear receptor involved in development, metabolism and steroidogenesis. Trends in Cell Biology 14 250-260.

Feldman DE, Chauhan V \& Koong AC 2005 The unfolded protein response: a novel component of the hypoxic stress response in tumors. Molecular Cancer Research 3 597-605.

Ferri K \& Kroemer G 2001 Mitochondria - the suicide organelles. BioEssays 23 111-115.

Flaig R, Greschik H, Peluso-Iltis C \& Moras D 2005 Structural basis for the cell-specific activities of the NGFI-B and the Nurr1 ligand-binding domain. Journal of Biological Chemistry 280 19250-19258.

Francis G, Fayard E, Picard F \& Auwerx J 2003 Nuclear receptors and the control of metabolism. Annual Review of Physiology 65 261-311.

Freedman LP, Luisi BF, Korszun ZR, Basavappa R, Sigler PB \& Yamamoto KR 1988 The function and structure of the metal coordination sites within the glucocorticoid receptor DNA binding domain. Nature 334 543-546.

Froy O 2010 Metabolism and circadian rhythms implications for obesity. Endocrine Reviews 31 1-24.

Gaillard S, Grasfeder L, Haeffele C, Lobenhofer E, Chu T, Wolfinger R, Kazmin D, Koves T, Muoio D, Chang C et al. 2006 Receptor-selective coactivators as tools to define the biology of specific receptor-coactivator pairs. Molecular Cell 24 797-803.

Gaillard S, Dwyer M \& McDonnell D 2007 Definition of the molecular basis for estrogen receptor-related receptoralpha-cofactor interactions. Molecular Endocrinology 21 $62-76$.

Garza AM, Khan SH \& Kumar R 2010 Site-specific phosphorylation induces functionally active conformation in the intrinsically disordered $\mathrm{N}$-terminal activation function (AF1) domain of the glucocorticoid receptor. Molecular and Cellular Biology 30 220-230.

Gearhart M, Holmbeck S, Evans R, Dyson H \& Wright P 2003 Monomeric complex of human orphan estrogen related receptor-2 with DNA: a pseudo-dimer interface mediates extended half-site recognition. Journal of Molecular Biology 327 819-832.

Giguere V 2008 Transcriptional control of energy homeostasis by the estrogen-related receptors. Endocrine Reviews 29 677-696. 
Gomez BP, Riggins RB, Shajahan AN, Klimach U, Wang A, Crawford AC, Zhu Y, Zwart A, Wang M \& Clarke R 2007 Human X-box binding protein-1 confers both estrogen independence and antiestrogen resistance in breast cancer cell lines. FASEB Journal 21 4013-4027.

Greschik H, Wurtz JM, Sanglier S, Bourguet W, van Dorsselaer A, Moras D \& Renaud JP 2002 Structural and functional evidence for ligand-independent transcriptional activation by the estrogen-related receptor 3 . Molecular Cell 9 303-313.

Greschik H, Flaig R, Renaud JP \& Moras D 2004 Structural basis for the deactivation of the estrogen-related receptor gamma by diethylstilbestrol or 4-hydroxytamoxifen and determinants of selectivity. Journal of Biological Chemistry 279 33639-33646.

Gu Z, Lee RY, Skaar TC, Bouker KB, Welch JN, Lu J, Liu A, Zhu Y, Davis N, Leonessa F et al. 2002 Association of interferon regulatory factor-1, nucleophosmin, nuclear factor-kappaB, and cyclic AMP response element binding with acquired resistance to faslodex (ICI 182,780). Cancer Research 62 3428-3437.

Gupta P, Park S, Farooqui M \& Wei L 2007 Orphan nuclear receptor TR2, a mediator of preadipocyte proliferation, is differentially regulated by RA through exchange of coactivator PCAF with corepressor RIP140 on a platform molecule GRIP1. Nucleic Acids Research 35 2269-2282.

Gurates B, Sebastian S, Yang S, Zhou J, Tamura M, Fang Z, Suzuki T, Sasano H \& Bulun S 2002 WT1 and DAX-1 inhibit aromatase $\mathrm{P} 450$ expression in human endometrial and endometriotic stromal cells. Journal of Clinical Endocrinology and Metabolism 87 4369-4377.

Gurates B, Amsterdam A, Tamura M, Yang S, Zhou J, Fang Z, Amin S, Sebastian S \& Bulun S 2003 WT1 and DAX-1 regulate SF-1-mediated human P450arom gene expression in gonadal cells. Molecular and Cellular Endocrinology 208 61-75.

Hall JM \& McDonnell DP 2005 Coregulators in nuclear estrogen receptor action: from concept to therapeutic targeting. Molecular Interventions 5 343-357.

Heck S, Rom J, Thewes V, Becker N, Blume B, Sinn H, Deuschle U, Sohn C, Schneeweiss A \& Lichter P 2009 Estrogen-related receptor alpha expression and function is associated with the transcriptional coregulator AIB1 in breast carcinoma. Cancer Research 69 5186-5193.

Helguero L, Hedengran Faulds M, Förster C, Gustafsson J \& Haldosén L 2006 DAX-1 expression is regulated during mammary epithelial cell differentiation. Endocrinology 147 3249-3259.

Horard B \& Vanacker JM 2003 Estrogen receptor-related receptors: orphan receptors desperately seeking a ligand. Journal of Molecular Endocrinology 31 349-357.

Hsieh J, Whitfield G, Oza A, Dang H, Price J, Galligan M, Jurutka P, Thompson P, Haussler C \& Haussler M 1999 Characterization of unique DNA-binding and transcriptional-activation functions in the carboxylterminal extension of the zinc finger region in the human vitamin D receptor. Biochemistry 38 16347-16358.
Hu Y, Shyr C, Che W, Mu X, Kim E \& Chang C 2002 Suppression of estrogen receptor-mediated transcription and cell growth by interaction with TR2 orphan receptor. Journal of Biological Chemistry 277 33571-33579.

Huppunen J, Wohlfahrt G \& Aarnisalo P 2004 Requirements for transcriptional regulation by the orphan nuclear receptor ERRgamma. Molecular and Cellular Endocrinology 219 151-160.

Hwang E, Lee J, Jeong J, Park J, Yang Y, Lim J, Kim J, Baek S \& Kim K 2009 SUMOylation of RORalpha potentiates transcriptional activation function. Biochemical and Biophysical Research Communications 378 513-517.

Jemal A, Siegel R, Ward E, Hao Y, Xu J \& Thun M 2009 Cancer statistics, 2009. CA: A Cancer Journal for Clinicians 59 225-249.

Jeong Y \& Mangelsdorf DJ 2009 Nuclear receptor regulation of stemness and stem cell differentiation. Experimental \& Molecular Medicine 41 525-537.

Jetten A 2004 Recent advances in the mechanisms of action and physiological functions of the retinoid-related orphan receptors (RORs). Current Drug Targets. Inflammation and Allergy 3 395-412.

Johansson L, Thomsen J, Damdimopoulos A, Spyrou G, Gustafsson J \& Treuter E 1999 The orphan nuclear receptor SHP inhibits agonist-dependent transcriptional activity of estrogen receptors ERalpha and ERbeta. Journal of Biological Chemistry 274 345-353.

Johnston S 2009 Enhancing the efficacy of hormonal agents with selected targeted agents. Clinical Breast Cancer 9 (Supplement 1) S28-S36.

Kallen J, Schlaeppi J, Bitsch F, Delhon I \& Fournier B 2004 Crystal structure of the human RORalpha ligand binding domain in complex with cholesterol sulfate at $2.2 \mathrm{~A}$. Journal of Biological Chemistry 279 14033-14038.

Kang H, Angers M, Beak J, Wu X, Gimble J, Wada T, Xie W, Collins J, Grissom S \& Jetten A 2007 Gene expression profiling reveals a regulatory role for ROR alpha and ROR gamma in phase I and phase II metabolism. Physiological Genomics 31 281-294.

Kim G, Lee G, Nedumaran B, Park Y, Kim K, Park S, Lee Y, Kim J \& Choi H 2008 The orphan nuclear receptor DAX-1 acts as a novel transcriptional corepressor of PPARgamma. Biochemical and Biophysical Research Communications 370 264-268.

Klinge C 1999 Role of estrogen receptor ligand and estrogen response element sequence on interaction with chicken ovalbumin upstream promoter transcription factor (COUP-TF). Journal of Steroid Biochemistry and Molecular Biology 71 1-19.

Klinge C, Silver B, Driscoll M, Sathya G, Bambara R \& Hilf R 1997 Chicken ovalbumin upstream promotertranscription factor interacts with estrogen receptor, binds to estrogen response elements and half-sites, and inhibits estrogen-induced gene expression. Journal of Biological Chemistry 272 31465-31474.

Kong W, Jiang X \& Mercer W 2009a Downregulation of Wip-1 phosphatase expression in MCF-7 breast cancer 
cells enhances doxorubicin-induced apoptosis through p53-mediated transcriptional activation of Bax. Cancer Biology \& Therapy 8 555-563.

Kong X, Fan H, Liu X, Wang R, Liang J, Gupta N, Chen Y, Fang F \& Chang Y $2009 b$ Peroxisome proliferatoractivated receptor gamma coactivator-1alpha enhances antiproliferative activity of $5^{\prime}$-deoxy-5-fluorouridine in cancer cells through induction of uridine phosphorylase. Molecular Pharmacology 76 854-860.

Koritschoner N, Madruga J, Knespel S, Blendinger G, Anzinger B, Otto A, Zenke M \& Bartůnĕk P 2001 The nuclear orphan receptor TR4 promotes proliferation of myeloid progenitor cells. Cell Growth \& Differentiation 12 563-572.

Kovacic A, Speed C, Simpson E \& Clyne C 2004 Inhibition of aromatase transcription via promoter II by short heterodimer partner in human preadipocytes. Molecular Endocrinology 18 252-259.

Krasowski MD, Reschly EJ \& Ekins S 2008 Intrinsic disorder in nuclear hormone receptors. Journal of Proteome Research 7 4359-4372.

Kraus RJ, Ariazi EA, Farrell ML \& Mertz JE 2002 Estrogenrelated receptor alpha 1 actively antagonizes estrogen receptor-regulated transcription in MCF-7 mammary cells. Journal of Biological Chemistry 277 24826-24834.

Kudo K, Xi Y, Wang Y, Song B, Chu E, Ju J \& Russo J 2010 Translational control analysis by translationally active RNA capture/microarray analysis (TrIP-Chip). Nucleic Acids Research 38 e104.

Kumar R \& Litwack G 2009 Structural and functional relationships of the steroid hormone receptors' N-terminal transactivation domain. Steroids 74 877-883.

Lacroix M \& Leclercq G 2004 About GATA3, HNF3A, and $\mathrm{XBP} 1$, three genes co-expressed with the oestrogen receptor-alpha gene (ESR1) in breast cancer. Molecular and Cellular Endocrinology 219 1-7.

Lanvin O, Bianco S, Kersual N, Chalbos D \& Vanacker J 2007 Potentiation of ICI182,780 (Fulvestrant)-induced estrogen receptor-alpha degradation by the estrogen receptor-related receptor-alpha inverse agonist XCT790. Journal of Biological Chemistry 282 28328-28334.

Le Dily F, Métivier R, Guéguen M, Le Péron C, Flouriot G, Tas P \& Pakdel F 2008 COUP-TFI modulates estrogen signaling and influences proliferation, survival and migration of breast cancer cells. Breast Cancer Research and Treatment 110 69-83.

Lee Y, Lee H \& Chang C 2002 Recent advances in the TR2 and TR4 orphan receptors of the nuclear receptor superfamily. Journal of Steroid Biochemistry and Molecular Biology 81 291-308.

Li Y, Choi M, Cavey G, Daugherty J, Suino K, Kovach A, Bingham N, Kliewer S \& Xu H 2005 Crystallographic identification and functional characterization of phospholipids as ligands for the orphan nuclear receptor steroidogenic factor-1. Molecular Cell 17 491-502.

Lin D \& Chang C 1996 p53 is a mediator for radiationrepressed human TR2 orphan receptor expression in
MCF-7 cells, a new pathway from tumor suppressor to member of the steroid receptor superfamily. Journal of Biological Chemistry 271 14649-14652.

Liu D, Zhang Z, Gladwell W \& Teng C 2003 Estrogen stimulates estrogen-related receptor alpha gene expression through conserved hormone response elements. Endocrinology 144 4894-4904.

Liu N, Lin W, Kim E, Collins L, Lin H, Yu I, Sparks J, Chen L, Lee Y \& Chang C 2007 Loss of TR4 orphan nuclear receptor reduces phosphoenolpyruvate carboxykinase-mediated gluconeogenesis. Diabetes 56 2901-2909.

Lu D, Kiriyama Y, Lee K \& Giguère V 2001 Transcriptional regulation of the estrogen-inducible pS2 breast cancer marker gene by the ERR family of orphan nuclear receptors. Cancer Research 61 6755-6761.

Lykkesfeldt A, Henriksen K, Rasmussen B, Sasano H, Evans D, Møller S, Ejlertsen B \& Mouridsen H 2009 In situ aromatase expression in primary tumor is associated with estrogen receptor expression but is not predictive of response to endocrine therapy in advanced breast cancer. BMC Cancer 9185.

Ma XJ, Wang Z, Ryan PD, Isakoff SJ, Barmettler A, Fuller A, Muir B, Mohapatra G, Salunga R, Tuggle JT et al. 2004 A two-gene expression ratio predicts clinical outcome in breast cancer patients treated with tamoxifen. Cancer Cell 5 607-616.

Macciò A, Madeddu C \& Mantovani G 2009 Adipose tissue as target organ in the treatment of hormone-dependent breast cancer: new therapeutic perspectives. Obesity Reviews 10 660-670.

Macedo L, Sabnis G \& Brodie A 2009 Aromatase inhibitors and breast cancer. Annals of the New York Academy of Sciences 1155 162-173.

Mangelsdorf DJ, Thummel C, Beato M, Herrlich P, Schutz G, Umesono K, Blumberg B, Kastner P, Mark M, Chambon P et al. 1995 The nuclear receptor superfamily: the second decade. Cell 83 835-839.

Marcotte R \& Muller W 2008 Signal transduction in transgenic mouse models of human breast cancer implications for human breast cancer. Journal of Mammary Gland Biology and Neoplasia 13 323-335.

Maring J, Groen H, Wachters F, Uges D \& de Vries E 2005 Genetic factors influencing pyrimidine-antagonist chemotherapy. Pharmacogenomics Journal 5 226-243.

Markićević M, Petrović A, Kanjer K, NeskovićKonstantinović Z \& Nikolić-Vukosavujević D 2008 Estrogen-regulated cut-off values of $\mathrm{pS} 2$ and cathepsin $\mathrm{D}$ expression in breast carcinomas. Advances in Experimental Medicine and Biology 617 341-348.

Métivier R, Gay F, Hübner M, Flouriot G, Salbert G, Gannon F, Kah O \& Pakdel F 2002 Formation of an hER alphaCOUP-TFI complex enhances hER alpha AF-1 through Ser118 phosphorylation by MAPK. EMBO Journal 21 3443-3453.

Miki Y, Clyne C, Suzuki T, Moriya T, Shibuya R, Nakamura Y, Ishida T, Yabuki N, Kitada K, Hayashi S et al. 2006 
Immunolocalization of liver receptor homologue-1 (LRH-1) in human breast carcinoma: possible regulator of in situ steroidogenesis. Cancer Letters 244 24-33.

Minezaki Y, Homma K, Kinjo AR \& Nishikawa K 2006

Human transcription factors contain a high fraction of intrinsically disordered regions essential for transcriptional regulation. Journal of Molecular Biology 359 1137-1149.

Moll U, Marchenko N \& Zhang X 2006 p53 and Nur77/TR3 - transcription factors that directly target mitochondria for cell death induction. Oncogene 25 4725-4743.

Moral R, Wang R, Russo IH, Lamartiniere CA, Pereira J \& Russo J 2008 Effect of prenatal exposure to the endocrine disruptor bisphenol A on mammary gland morphology and gene expression signature. Journal of Endocrinology 196 101-112.

Moré E, Fellner T, Doppelmayr H, Hauser-Kronberger C, Dandachi N, Obrist P, Sandhofer F \& Paulweber B 2003 Activation of the MAP kinase pathway induces chicken ovalbumin upstream promoter-transcription factor II (COUP-TFII) expression in human breast cancer cell lines. Journal of Endocrinology 176 83-94.

Musgrove E \& Sutherland R 2009 Biological determinants of endocrine resistance in breast cancer. Nature Reviews. Cancer 9 631-643.

Nakshatri H, Mendonca M, Bhat-Nakshatri P, Patel N, Goulet RJ \& Cornetta K 2000 The orphan receptor COUP-TFII regulates G2/M progression of breast cancer cells by modulating the expression/activity of p21(WAF1/CIP1), cyclin D1, and cdk2. Biochemical and Biophysical Research Communications 270 1144-1153.

Novac N \& Heinzel T 2004 Nuclear receptors: overview and classification. Current Drug Targets. Inflammation and Allergy 3 335-346.

Odawara H, Iwasaki T, Horiguchi J, Rokutanda N, Hirooka K, Miyazaki W, Koibuchi Y, Shimokawa N, Iino Y, Takeyoshi I et al. 2009 Activation of aromatase expression by retinoic acid receptor-related orphan receptor (ROR) alpha in breast cancer cells: identification of a novel ROR response element. Journal of Biological Chemistry 284 17711-17719.

Ohkubo T, Ohkura N, Maruyama K, Sasaki K, Nagasaki K, Hanzawa H, Tsukada T \& Yamaguchi K 2000 Early induction of the orphan nuclear receptor NOR-1 during cell death of the human breast cancer cell line MCF-7. Molecular and Cellular Endocrinology 162 151-156.

Olopade O, Grushko T, Nanda R \& Huo D 2008 Advances in breast cancer: pathways to personalized medicine. Clinical Cancer Research 14 7988-7999.

O’Malley BW \& Kumar R 2009 Nuclear receptor coregulators in cancer biology. Cancer Research 69 8217-8222.

Orlando F \& Brown K 2009 Unraveling breast cancer heterogeneity through transcriptomic and epigenomic analysis. Annals of Surgical Oncology 16 2270-2279.

Ortlund E, Lee Y, Solomon I, Hager J, Safi R, Choi Y, Guan Z, Tripathy A, Raetz C, McDonnell D et al. 2005
Modulation of human nuclear receptor LRH-1 activity by phospholipids and SHP. Nature Structural \& Molecular Biology 12 357-363.

Paik S, Shak S, Tang G, Kim C, Baker J, Cronin M, Baehner FL, Walker MG, Watson D, Park T et al. 2004 A multigene assay to predict recurrence of tamoxifentreated, node-negative breast cancer. New England Journal of Medicine 351 2817-2826.

Parton M, Krajewski S, Smith I, Krajewska M, Archer C, Naito M, Ahern R, Reed J \& Dowsett M 2002 Coordinate expression of apoptosis-associated proteins in human breast cancer before and during chemotherapy. Clinical Cancer Research 8 2100-2108.

Pereira F, Qiu Y, Zhou G, Tsai M \& Tsai S 1999 The orphan nuclear receptor COUP-TFII is required for angiogenesis and heart development. Genes and Development 13 1037-1049.

Rae JM, Ramus SJ, Waltham M, Armes JE, Campbell IG, Clarke R, Barndt RJ, Johnson MD \& Thompson EW 2004 Common origins of MDA-MB-435 cells from various sources with those shown to have melanoma properties. Clinical \& Experimental Metastasis 21 543-552.

Rajhans R, Nair H, Nair S, Cortez V, Ikuko K, Kirma N, Zhou D, Holden A, Brann D, Chen S et al. 2008 Modulation of in situ estrogen synthesis by proline-, glutamic acid-, and leucine-rich protein-1: potential estrogen receptor autocrine signaling loop in breast cancer cells. Molecular Endocrinology 22 649-664.

Reis-Filho JS, Simpson PT, Turner NC, Lambros MB, Jones C, Mackay A, Grigoriadis A, Sarrio D, Savage K, Dexter T et al. 2006 FGFR1 emerges as a potential therapeutic target for lobular breast carcinomas 17372 . Clinical Cancer Research 12 6652-6662.

Rhodes DR, Yu J, Shanker K, Deshpande N, Varambally R, Ghosh D, Barrette T, Pandey A \& Chinnaiyan AM 2004 ONCOMINE: a cancer microarray database and integrated data-mining platform. Neoplasia 6 1-6.

Riggins R, Bouton AH, Liu MC \& Clarke R 2005 Antiestrogens, aromatase inhibitors, and apoptosis in breast cancer. Vitamins and Hormones 71 201-237.

Riggins RB, Schrecengost RS, Guerrero MS \& Bouton AH 2007 Pathways to tamoxifen resistance. Cancer Letters $2561-24$.

Riggins RB, Lan JP, Zhu Y, Klimach U, Zwart A, Cavalli LR, Haddad BR, Chen L, Gong T, Xuan J et al. 2008 ERR $\gamma$ mediates tamoxifen resistance in novel models of invasive lobular breast cancer. Cancer Research 68 8908-8917.

Riggs K, Wickramasinghe N, Cochrum R, Watts M \& Klinge C 2006 Decreased chicken ovalbumin upstream promoter transcription factor II expression in tamoxifenresistant breast cancer cells. Cancer Research $\mathbf{6 6}$ 10188-10198.

Robinson-Rechavi M, Garcia HE \& Laudet V 2003 The nuclear receptor superfamily. Journal of Cell Science 116 585-586.

Safi R, Kovacic A, Gaillard S, Murata Y, Simpson E, McDonnell D \& Clyne C 2005 Coactivation of liver 
receptor homologue-1 by peroxisome proliferator-activated receptor gamma coactivator-1alpha on aromatase promoter II and its inhibition by activated retinoid X receptor suggest a novel target for breast-specific antiestrogen therapy. Cancer Research 65 11762-11770.

Sahar S \& Sassone-Corsi P 2009 Metabolism and cancer: the circadian clock connection. Nature Reviews. Cancer 9 886-896.

Santen R, Brodie H, Simpson E, Siiteri P \& Brodie A 2009 History of aromatase: saga of an important biological mediator and therapeutic target. Endocrine Reviews 30 343-375.

Schoenmakers E, Alen P, Verrijdt G, Peeters B, Verhoeven G, Rombauts W \& Claessens F 1999 Differential DNA binding by the androgen and glucocorticoid receptors involves the second $\mathrm{Zn}$-finger and a C-terminal extension of the DNA-binding domains. Biochemical Journal 341 515-521.

Schultz J, Loven M, Melvin V, Edwards D \& Nardulli A 2002 Differential modulation of DNA conformation by estrogen receptors alpha and beta. Journal of Biological Chemistry 277 8702-8707.

Sentis S, Le Romancer M, Bianchin C, Rostan M \& Corbo L 2005 Sumoylation of the estrogen receptor alpha hinge region regulates its transcriptional activity. Molecular Endocrinology 19 2671-2684.

Seol W, Choi H \& Moore D 1996 An orphan nuclear hormone receptor that lacks a DNA binding domain and heterodimerizes with other receptors. Science $\mathbf{2 7 2}$ 1336-1339.

Shajahan A, Riggins R \& Clarke R 2008 Apoptosis, cell death, and breast cancer. In Breast Cancer: Prognosis, Treatment, and Prevention, edn 2, ch 8, pp 137-155. Ed J Pasqualini. New York, NY, USA: Informa Healthcare.

Shyr C, Hu Y, Kim E \& Chang C 2002 Modulation of estrogen receptor-mediated transactivation by orphan receptor TR4 in MCF-7 cells. Journal of Biological Chemistry 277 14622-14628.

Sorlie T, Perou CM, Tibshirani R, Aas T, Geisler S, Johnsen H, Hastie T, Eisen MB, Van de RM, Jeffrey SS et al. 2001 Gene expression patterns of breast carcinomas distinguish tumor subclasses with clinical implications. PNAS 98 10869-10874.

Sorlie T, Tibshirani R, Parker J, Hastie T, Marron JS, Nobel A, Deng S, Johnsen H, Pesich R, Geisler S et al. 2003 Repeated observation of breast tumor subtypes in independent gene expression data sets. PNAS 100 8418-8423.

Stein R \& McDonnell D 2006 Estrogen-related receptor alpha as a therapeutic target in cancer. Endocrine-Related Cancer 13 (Supplement 1) S25-S32.

Stein R, Chang C, Kazmin D, Way J, Schroeder T, Wergin M, Dewhirst M \& McDonnell D 2008 Estrogen-related receptor alpha is critical for the growth of estrogen receptor-negative breast cancer. Cancer Research 68 8805-8812.
Stein R, Gaillard S \& McDonnell D 2009 Estrogen-related receptor alpha induces the expression of vascular endothelial growth factor in breast cancer cells. Journal of Steroid Biochemistry and Molecular Biology 114 106-112.

Surowiak P, Materna V, Györffy B, Matkowski R, Wojnar A, Maciejczyk A, Paluchowski P, Dziegiel P, Pudełko M, Kornafel J et al. 2006 Multivariate analysis of oestrogen receptor alpha, $\mathrm{pS} 2$, metallothionein and $\mathrm{CD} 24$ expression in invasive breast cancers. British Journal of Cancer 95 339-346.

Suzuki T, Miki Y, Moriya T, Shimada N, Ishida T, Hirakawa H, Ohuchi N \& Sasano H 2004 Estrogen-related receptor alpha in human breast carcinoma as a potent prognostic factor. Cancer Research 64 4670-4676.

Takimoto GS, Tung L, Abdel-Hafiz H, Abel MG, Sartorius CA, Richer JK, Jacobsen BM, Bain DL \& Horwitz KB 2003 Functional properties of the N-terminal region of progesterone receptors and their mechanistic relationship to structure. Journal of Steroid Biochemistry and Molecular Biology 85 209-219.

Tamasi V, Miller KK, Ripp SL, Vila E, Geoghagen TE \& Prough RA 2008 Modulation of receptor phosphorylation contributes to activation of peroxisome proliferator activated receptor alpha by dehydroepiandrosterone and other peroxisome proliferators. Molecular Pharmacology 73 968-976.

Tanabe O, Shen Y, Liu Q, Campbell A, Kuroha T, Yamamoto M \& Engel J 2007 The TR2 and TR4 orphan nuclear receptors repress Gata1 transcription. Genes and Development 21 2832-2844.

Tozlu S, Girault I, Vacher S, Vendrell J, Andrieu C, Spyratos F, Cohen P, Lidereau R \& Bieche I 2006 Identification of novel genes that co-cluster with estrogen receptor alpha in breast tumor biopsy specimens, using a large-scale real-time reverse transcription-PCR approach. EndocrineRelated Cancer 13 1109-1120.

Tremblay AM \& Giguere V 2007 The NR3B subgroup: an ovERRview. Nuclear Receptor Signaling 5 e009.

Tremblay AM, Wilson BJ, Yang XJ \& Giguere V 2008 Phosphorylation-dependent sumoylation regulates estrogen-related receptor-alpha and -gamma transcriptional activity through a synergy control motif. Molecular Endocrinology 22 570-584.

Vu EH, Kraus RJ \& Mertz JE 2007 Phosphorylationdependent sumoylation of estrogen-related receptor alpha1. Biochemistry 46 9795-9804.

Wang Z, Jeffs B, Ito M, Achermann J, Yu R, Hales D \& Jameson J 2001 Aromatase (Cyp19) expression is up-regulated by targeted disruption of Dax1. PNAS 98 7988-7993.

Wang Z, Benoit G, Liu J, Prasad S, Aarnisalo P, Liu X, Xu H, Walker N \& Perlmann T 2003 Structure and function of Nurr1 identifies a class of ligand-independent nuclear receptors. Nature 423 555-560.

Westin S, Kurokawa R, Nolte RT, Wisely GB, McInerney EM, Rose DW, Milburn MV, Rosenfeld MG \& Glass CK 1998 Interactions controlling the assembly of nuclear-receptor heterodimers and co-activators. Nature 395 199-202. 
Wilson B \& Giguère V 2008 Meta-analysis of human cancer microarrays reveals GATA3 is integral to the estrogen receptor alpha pathway. Molecular Cancer 749.

Wilson B, Tremblay A, Deblois G, Sylvain-Drolet G \& Giguère V 2010 An acetylation switch modulates the transcriptional activity of estrogen-related receptor $\alpha$. Molecular Endocrinology 24 1349-1358.

Wisely G, Miller A, Davis R, Thornquest AJ, Johnson R, Spitzer T, Sefler A, Shearer B, Moore J, Willson T et al. 2002 Hepatocyte nuclear factor 4 is a transcription factor that constitutively binds fatty acids. Structure $\mathbf{1 0}$ 1225-1234.

Wu F, Wang J, Wang Y, Kwok T, Kong S \& Wong C 2009 Estrogen-related receptor alpha (ERRalpha) inverse agonist XCT-790 induces cell death in chemotherapeutic resistant cancer cells. Chemico-Biological Interactions $\mathbf{1 8 1}$ 236-242.

Wurtz J, Bourguet W, Renaud J, Vivat V, Chambon P, Moras D \& Gronemeyer H 1996 A canonical structure for the ligand-binding domain of nuclear receptors. Nature Structural Biology 3 87-94.
Zhang H, Thomsen J, Johansson L, Gustafsson J \& Treuter E 2000 DAX-1 functions as an LXXLL-containing corepressor for activated estrogen receptors. Journal of Biological Chemistry 275 39855-39859.

Zhang T, Jia N, Fei E, Wang P, Liao Z, Ding L, Yan M, Nukina N, Zhou J \& Wang G 2007 Nurr1 is phosphorylated by ERK2 in vitro and its phosphorylation upregulates tyrosine hydroxylase expression in SH-SY5Y cells. Neuroscience Letters 423 118-122.

Zhang T, Wang P, Ren H, Fan J \& Wang G 2009 NGFI-B nuclear orphan receptor Nurr1 interacts with p53 and suppresses its transcriptional activity. Molecular Cancer Research 7 1408-1415.

Zhou J, Suzuki T, Kovacic A, Saito R, Miki Y, Ishida T, Moriya T, Simpson E, Sasano H \& Clyne C 2005 Interactions between prostaglandin $\mathrm{E}(2)$, liver receptor homologue-1, and aromatase in breast cancer. Cancer Research 65 657-663.

Zhu Y, McAvoy S, Kuhn R \& Smith D 2006 RORA, a large common fragile site gene, is involved in cellular stress response. Oncogene 25 2901-2908. 